\title{
La idea de una filosofía cristiana en Ignacio Ellacuría
}

Héctor Samour ${ }^{1}$

Recibido el 01 de octubre del 2013, aceptado el 25 de octubre del 2013

\begin{abstract}
Resumen
El objetivo primario de este artículo es conocer la filosofía temprana de Ignacio Ellacuría, con el fin de identificar las raíces de su filosofía madura, así como los temas e intereses filosóficos que le llevaron a asumir la filosofía de Zubiri como base de su reflexión filosófica más original.

Palabras claves

Filosofía integradora, filosofía cristiana, neoescolastica, pensamiento vital y humano, realidad histórica

Abstract

This article is mainly concerned with the early philosophical work of Ignacio Ellacuria, in order to identify the roots of his later mature philosophical thought as well as to identify the philosophical topics and interests that let him base his most original reflection on Zubiri's philosophy.
\end{abstract}

Keywords

integrative philosophy, Christian philosophy, Neo-Scholasticism, vital human thinking, historical reality

Este trabajo está orientado a analizar los aspectos principales del pensamiento filosófico de Ignacio Ellacuría en su etapa juvenil, de 1950-1962. En este período Ellacuría intenta construir una filosofía a la altura de los tiempos, a partir de la síntesis de lo antiguo y lo moderno, con el fin de dar una respuesta filosófica a los problemas vitales y existenciales del ser humano en las sociedades capitalistas contemporáneas. En esta línea Ellacuría busca sentar las bases para formular una filosofía integradora, con un profundo sentido humanista, que corrija lo que de pensamiento intelectualista y abstracto tiene la escolástica. Para ello verá necesario partir de una filosofía cristiana como la desarrollada por santo Tomás, pero complementada existencial y vitalmente por lo que él denomina "filosofía vitalista moderna", representada por Ortega y Gasset. Su interés primario en este esfuerzo de complementación o conciliación es lograr una visión unitaria del ser humano que conceptúe adecuadamente la unidad

1. Vice Ministro de Educación de El Salvador. E-mail: hectorsamour@uca.edu.sv 
de las dimensiones que están implicadas en la realidad humana: lo natural y lo sobrenatural, la necesidad y la libertad, la esencia y la existencia, lo inmanente y lo trascendente. Ellacuría piensa que la principal contribución de la filosofía en el proceso de la liberación humana es lograr una interpretación esencial del ser humano que sea operativa en la consecución de ese fin. Las raíces de este esfuerzo, sus características principales y sus resultados es lo que abordaremos en las páginas siguientes.

\section{Filosofar para humanizar}

Las características de la reflexión filosófica de Ellacuría en esta época reflejan en parte lo que era la Neoescolástica como movimiento intelectual dominante dentro de la iglesia católica de la época. El intento de sintetizar lo antiguo (santo Tomás o en ocasiones Suárez) con lo nuevo (Kant primero, después Blondel, Bergson, Husserl o Heidegger) era un rasgo característico del ambiente de la época, del cual ciertamente participaba el joven Ellacuría. Sin embargo, a mi juicio, no fue primariamente la influencia de esta corriente la que determinó las características de su filosofar. Las raíces de la orientación de su pensamiento filosófico hay que buscarlas en sus estudios humanísticos y filosóficos de Quito, especialmente en el impacto que causaron en él los magisterios de Aurelio Espinosa Pólit y Ángel Martínez Baigorri.

Espinosa Pólit fue uno de los maestros que tuvo Ellacuría durante sus estudios de humanidades clásicas y filosofía en la Universidad Católica de Quito. Era Rector de la Universidad, poeta y asesor del gobierno ecuatoriano en asuntos culturales, y una autoridad mundial reconocida en Sófocles y Virgilio. Era, además, un gran humanista muy apreciado por la sociedad ecuatoriana de la época, autor de estudios sobre pensadores ecuatorianos y sobre temas religiosos, filosóficos y sobre teoría de la educación. ${ }^{2}$ Con ocasión de su muerte en 1961, Ellacuría escribió un artículo en homenaje a su maestro, que se publicó en ECA en 1963 . $^{3}$ En dicho artículo Ellacuría expresa su admiración por la profunda penetración humana e intelectual de Espinosa en el terreno de las Humanidades clásicas y por su forma de vivir el sacerdocio entroncado con el humanismo.

Ángel Martínez fue uno de los poetas más importantes de Nicaragua, también jesuita y navarro. Durante su estancia en Quito, en octubre de 1954, Ángel Martínez dictó una serie de conferencias sobre metafísica, estética y poesía

2 Cfr. R. Cardenal, "Ser jesuita hoy en El Salvador", Revista Estudios Centroamericanos (ECA), Nos. 493-494, 1989, pp. 1013-1014; R. Cardenal, "De Portugalete a San Salvador", en J. Sobrino y R. Alvarado, Ignacio Ellacuría. "Aquella libertad esclarecida", UCA Editores, San Salvador, 1999, pp 45 ss.

3 “El p. Aurelio Espinosa Pólit, S.J.”, ECA, No. 178, 1963, pp. 21-24. 
a los jesuitas que hacían sus estudios de filosofía. A partir de este encuentro, Ellacuría supo reconocer el genio y la vida poéticas de Martínez. ${ }^{4}$ Desde entonces entablaron una profunda amistad y se escribieron durante algunos años. Ellacuría escribió dos artículos sobre su poesía, uno de ellos redactado a mano probablemente en $1956^{5}$, y otro que fue publicado en la Revista Cultura del Ministerio de Educación de El Salvador en 1958, bajo el título “Ángel Martínez, poeta esencial". ${ }^{6}$

De Espinosa Pólit, Ellacuría aprendió a colocar lo humano como raíz de la vida intelectual y cultural, y la necesidad, por tanto, de enfocar las disciplinas, y sobre todo la filosofía, de un modo humano, al colocar al ser humano en el centro de sus reflexiones. Ellacuría se refiere a él, de la siguiente manera:

No le despertaba interés, sino desasosiego, aquellas disciplinas que, aun objetivamente humanas, no veía enfocadas de modo suficientemente humano. Allí donde había un predominio de facultades, sobre todo discursivas, con menoscabo de otras, o una incapacidad de expresión humana que no dejaba traslucir un fondo de hombre íntegramente humano, se sentía a disgusto. Ciertamente, admitía tales disciplinas, en especial la filosofía, como momentos parciales en la formación integral del hombre, pero lo que no se le hacía tolerable era que el estilo propio de ellas, tal como las había visto vividas, llegase a ser el fundamental de una vida. ${ }^{7}$

Otro aspecto relevante del magisterio de Aurelio Espinosa fue el análisis existencial de situaciones humanas límites, realizado en sus clases a través de la lectura de textos clásicos. Esto no sólo introdujo a Ellacuría en el conocimiento de la problemática existencial del ser humano y de las corrientes existencialistas que la abordaban, sino que, además, le llevó a la convicción de la necesidad de un contacto total y directo con lo humano, como condición previa para su conocimiento pleno. Ellacuría expresa este aspecto, así:

La profunda persuasión de que lo humano - ¿y qué de lo que es capital para el hombre no es humano?- sólo se llega a conocer si se logra un contacto total con ello; el ir, como a meta de su

\footnotetext{
4 Cfr. R. Cardenal, “Ser jesuita hoy en El Salvador”, op.cit. pp. 1013-1014.

5 “Ángel Martínez Baigorri”.

6 Cfr. “Ángel Martínez, poeta esencial”, Revista Cultura, No. 14, 1958, pp. 123-164.

7 “El p. Aurelio Espinosa Pólit, S.J.”, en Escritos Filosóficos I, UCA Editores, San Salvador, 1996, p 528 (En adelante los citaremos como EF I, antecedido del artículo de Ellacuría correspondiente).
} 
formación, a lograr ese contacto, que no sólo da la vivencia más rica, sino la posibilidad misma de vivenciar potentemente; el llevarlo a cabo por medio de un análisis existencial y una recreación efectiva de modelos egregios de plenitud vital, son los reflejos y la comprobación más contundente de su condición excepcional de persona y maestro. ${ }^{8}$

Finalmente, hay que mencionar la vinculación del humanismo con el cristianismo, como otro aspecto importante de la influencia de Aurelio Espinosa. La idea de que se hace cristianismo construyendo lo humano y de que la mejor manera de ser cristiano es ser plenamente humano, son aspectos fundamentales que marcarán a Ellacuría tanto en su vida personal y sacerdotal, como en la orientación de su filosofía hacia la resolución del problema humano en las sociedades contemporáneas. Para Ellacuría, el P. Espinosa no presentaba fisuras entre su vocación humana y el cristianismo:

Ni su sacerdocio se presentaba sin humanismo ni su humanismo sin su sacerdocio [...] Como el mismo Justino, veía la posibilidad de edificar el cristiano, que nunca puede ni debe dejar de ser hombre, con lo que de mejor han producido los hombres. ${ }^{9}$

La insatisfacción con la escolástica como pensamiento desencarnado e intelectualista, la necesidad de humanizarla enderezándola hacia la problemática existencial y vital de los seres humanos concretos y su apertura a las corrientes existencialistas y vitalistas, son todas características del pensamiento filosófico de Ignacio Ellacuría que encuentran su raíz en el magisterio de Aurelio Espinosa.

Sin embargo, la influencia más decisiva en el estilo y en la dirección fundamental de la filosofía de Ellacuría, en esta etapa, la ejerció el poeta Ángel Martínez. En sus escritos juveniles se puede observar el poderoso influjo que ejerció el poeta en su personalidad, en su visión de la realidad y en el modo de filosofar sobre ella. Además, la obra de Ángel Martínez dotó a Ellacuría de una visión crítica de la civilización occidental y de los problemas humanos y sociales que padecían las sociedades capitalistas avanzadas y los países pobres que se encontraban bajo su órbita, en la década de los cincuenta. Es a partir de esta crítica a la civilización occidental que Ellacuría -dotado ya de por sí de un natural talante crítico- ${ }^{10}$ empezará a sentirse insatisfecho con el pensamiento escolástico como 
un pensamiento válido para responder y solucionar los problemas humanos que causa el capitalismo contemporáneo. Por ello, sin abandonar el núcleo de la metafísica aristotélico-tomista -que él considera en este momento básicamente acertada para explicar la realidad- Ellacuría intentará actualizarla y vitalizarla, tratando de conciliarla con el pensamiento filosófico contemporáneo en boga hasta ese momento.

Es interesante observar cómo muchos aspectos de la visión crítica, del Ellacuría maduro, a la civilización del capital, tienen sus raíces en esta crítica que desarrolló tempranamente de la mano del poeta. En el análisis que realiza de su obra se presenta un diagnóstico de los males del capitalismo contemporáneo, sobre todo del capitalismo estadounidense, juzgado desde una visión cristiana. ${ }^{11}$ Para Ellacuría el juicio último, resultante del análisis de las sociedades actuales, es que la actual civilización, hegemonizada por los Estados Unidos, somete a los seres humanos a un modo de ser y de vivir que los aliena de su ser verdadero, de su esencia religiosa, al reducirlos a su ser sensitivo y apariencial y al cortarles "la posibilidad misma de lo espiritual". En la civilización occidental predomina un "materialismo de la abundancia", que conlleva todo un "sentido de dispersión, alienación y deshumanización", por lo cual es "superficial, empobrecedor de toda la existencia a la que impele a una forma de ser fácil, pero falsa e inauténtica".12

Esta crítica condicionó de tal manera su forma de entender la filosofía y la función que debe desempeñar en el ámbito personal y social, que es algo que Ellacuría no abandonará a lo largo de su evolución intelectual. La filosofía debe ser un saber último y radical de la realidad, cuya principal función es posibilitar que los seres humanos reorienten sus vidas racionalmente, en el sentido que actúen conforme a la verdad de su ser y del ser de las cosas. La civilización contemporánea ha alienado a los seres humanos de su ser verdadero, al conducirlos por la vía de la superficialidad, el consumismo y el hedonismo, hacia una existencia vacía e inauténtica, y a la negación de su esencia religiosa, que constituye el núcleo de su ser. Se trata, por tanto, de que el hombre reconcilie su existencia vital con su esencia verdadera, que han sido separadas en esta circunstancia histórica. En esta tarea, la filosofía juega un papel de primer orden debido a la naturaleza de su saber y a su enorme potencialidad para encontrar la verdad y el ser de las cosas, más allá de las apariencias y de lo superficial. En el esfuerzo de filosofar para producir una

11 Cfr. “Ángel Martínez, poeta esencial”, EF I, pp.130-151. Aquí Ellacuría analiza detalladamente el libro de Martínez El Ángel en el país del águila, publicado en Madrid, en 1954.

12 Ibídem, p. 131. 
filosofía verdadera, siempre hay que partir de la propia circunstancia histórica y del contacto inmediato con la realidad, y darle prioridad a éstas por encima de los conceptos y de las teorías.

En su escrito de 1956 sobre la obra del poeta, Ellacuría reconoce el impacto que tuvo Ángel Martínez en su formación:

[...] me di cuenta que ha sido él el único hombre, tal vez, que me ha hecho olvidarme de mí mismo -de preocupaciones, de tendencias y aun de pasiones- y ha logrado que con todo mi ser atienda el objeto que él presentaba. ${ }^{13}$

Y en la correspondencia que mantuvo con él, se expresa así:

[...] pero usted puede ver en estos ligeros comentarios [...] como su vida resuena en la mía, en lo más hondo y en lo espiritual de ella [...] Espero seguirle por toda su carrera ad montem qui Christus est por la tierra llena de cielo que luego se va al mar; y por el mar al río hasta la otra tierra -Tierra Firme del Mar. Luego, otra vez por el río al mar, al Ultramar, al Cielo, al Ultracielo. Me parece que así vamos desde los posibles que un día fuimos hasta los futuros que por otra eternidad seremos, pasando por este tiempo en que vamos siendo. Yo todavía no entiendo esto muy bien, pero pienso que cuando lo comprenda, una vez que esté todo realizado y lo pueda leer, sentir y vivir, me encontraré con una síntesis en que resonará mi vida. Como ve, mi vida también es querer llegar, querer llegar, pero sin convencerme todavía, por lo menos en lo más íntimo debido a mis años jóvenes que apenas no son sino una esperanza, sin convencerme de que no llegaré nunca. También dentro de mí llevo un mundo de voces que aún no se pronuncian nítidas, que no sé dónde nacieron y que todavía no aciertan con su realización ni su expresión. ${ }^{14}$

Estas afirmaciones, principalmente, muestran dos cosas: en primer lugar, la enorme influencia de la personalidad y la obra de Ángel Martínez en la vida personal y en el pensamiento de Ignacio Ellacuría; en segundo lugar, que Ellacuría se encuentra, en este momento, en una actitud de búsqueda y definición de 
su proyecto de vida y de su propia orientación intelectual y filosófica, y no tiene, por tanto, un proyecto filosófico nítidamente definido con anterioridad, que fuera el centro en torno al cual girara su actividad teórica. Se trata de una actitud de aprovechamiento, asimilación y de crítica de todo lo recibido en el contexto cultural e ideológico de su formación, y que le llevará a buscar un pensamiento más vital y humano, características que él no percibía en las posturas escolásticas más ortodoxas de la época. Es importante tener en cuenta esto para no encajonar el pensamiento de filosófico de Ellacuría en un presunto proyecto filosófico a priori, que estaría informando la mayor parte de su obra filosófica y teológica, desde el propio arranque de su producción intelectual. Que esto es así, lo expresa con claridad el mismo Ellacuría:

Lo que trato es de buscar una base filosófica de mi posición ante la vida en el sentido de exigir una actitud vital de todo el hombre y además "recreadora", para uno mismo y para los otros, de las comunicaciones vivas de cualquier ser sobre la propia alma. Ya sé que esto trae muchos problemas y aun misterios que no he de poder resolver solo ni tal vez acompañado, pero no será de escaso fruto saber los límites del conocimiento en la materia y los puntos fijos a qué atenerse. ${ }^{15}$

Y en otra parte, dice:

Descubrir y declarar nominalmente las tesis en todas sus partes, no es cosa que me traiga mayor dificultad, por más que aun en eso, al ponerse las cosas un poco más ásperas, los textos muy generalmente escabullen el cuerpo. Donde me las veo y me las traigo es en el empeño de desentrañar esas palabras y esos conceptos, de soplar sobre ellos el aliento de la verdadera verdad y de la vera vida. Y después en transmitir esa luz y vida. No quisiera ser mero repetidor mecánico de esquemas muertos. $^{16}$

La síntesis filosófica que Ellacuría pretenderá realizar entre el pensamiento clásico y el moderno, es algo que él fue definiendo a lo largo de sus años de formación, a partir de su propia experiencia personal, de los problemas humanos y sociales que percibía y de lo que fue asimilando de sus principales maestros. De hecho, no es sino hasta 1958, cuando, por primera vez, Ellacuría 
habla expresamente sobre la necesidad de un pensamiento nuevo, producto de la síntesis integradora de la filosofía escolástica y la filosofía vitalista moderna. ${ }^{17}$ Los años anteriores habían sido de asimilación, de descubrimientos, de crítica y de reflexión personal hasta encontrar la solución teórica que él creía más acorde con las propias convicciones y que se le presentaba más racional de cara a las exigencias de la realidad y de su humanización.

Un elemento crucial en este proceso fue la influencia de la obra poética de Ángel Martínez. Precisamente uno de los aspectos que más valora Ellacuría de la obra del poeta es que representa una superación tanto de las posiciones escolásticas como de las expresiones vitales modernas, que Ellacuría juzga parciales e incompletas:

En lo que al P. Ángel respecta, su poesía es moderna por la autenticidad con que afronta los temas capitales y dolorosos del hombre en nuestro tiempo, y por la sinceridad con que se aprovecha de las purificaciones estéticas y técnicas que el arte moderno ha ido ganando desde el final del romanticismo hasta nuestros días. Pero, a su vez, es poesía sin tiempo -como gusta apellidarla el mismo poeta-, y aun sin espacio, porque a fuerza de ahondamiento se transciende hasta donde le es dado al hombre, lo que nos minimiza en momentos vacíos y en situaciones excesivamente locales; es poesía intemporal e inespacial en cuanto está alimentada con lo permanente y universal de los mejores poetas de las distintas literaturas. ${ }^{18}$

Ellacuría pretenderá realizar en el campo filosófico la síntesis entre lo intemporal y lo moderno que ha realizado Ángel Martínez en el campo poético, es decir, realizar una filosofía que sea a la vez perenne y moderna; esto es, una filosofía con un profundo sentido humano y ético, dotada a la vez de un amplio y sólido bagaje metafísico. Para Ellacuría quedarse sólo con lo moderno es resignarse a una filosofía superficial, sin capacidad de ahondar en el ser de las cosas; pero, a su vez, sólo quedarse con lo permanente y universal de la filosofía perenne, es ubicarse en una postura conservadora, cerrada a las expresiones modernas y a los problemas más acuciantes del tiempo presente.

Así como la poesía de Ángel Martínez es vital y esencial, la filosofía debe ser también vital y esencial, pero donde la "y" no es un mero añadido, sino algo

17 "Posibilidad y modo de aproximación entre la filosofía escolástica y la filosofía vitalista moderna”, texto redactado en junio de 1958, EF I, pp 223-244.

18 “Ángel Martínez, poeta esencial”, EF I, p.152. 
que expresa la unidad intrínseca de los dos términos: una filosofía que pretende dar respuesta a los problemas vitales del ser humano, en una situación histórica concreta, tiene forzosamente que ahondar en la realidad, hasta "ponerse en contacto con las cosas, con la esencia y vida de las cosas en orden a desvelarlas y revelarlas"19; de otra manera, no tendría el suficiente fundamento para iluminar y orientar la vida humana. A su vez, una filosofía, al estar abierta al ser y buscar lo más esencial de la realidad, tiene necesariamente que potenciar la existencia humana por cuanto el posible saber esencial que se va logrando representa una "liberación de la esclavitud en que vivimos, esclavitud en que nos mantienen las cosas y la parte más superficial, más carnal, de nosotros mismos". ${ }^{20}$ El mismo esfuerzo de indagar la esencia de lo real, implica una liberación del ser humano "que ni se extravía en solipsios (sic) infructuosos, ni se pierde, ni se aliena -se cosifica- entre ese lo otro que nos rodea". ${ }^{21}$

\section{La filosofía como forma de vida}

En el planteamiento anterior se basa la idea ellacuriana de la filosofía como una forma de vida, que es una constante en sus primeros escritos y desde la cual crítica el modo escolástico de entender la filosofía, y, en general, a "todos los escolasticismos, llámense tomistas, marxistas, idealistas o existencialistas"22. El pensamiento filosófico debe incluir como momentos intrínsecos suyos la actitud vital que lo posibilita como auténtica forma de vida y el conocimiento metafísico que se tiene de la realidad, condicionado en parte por aquella actitud vital. No hay otra manera, para Ellacuría, de producir filosofía auténtica. "Cuando la formulación refleja y la explicitación última son en apariencia filosóficas, porque su formato y su técnica lo son, pero no responden a aquella actitud problemática y al conocimiento vital previos, entonces, no es que la filosofía se desvitalice, es que deja de ser filosofía auténtica"23. Y cuando esto sucede, la filosofía se convierte en pura discusión de razones o en manejo de teorías y conceptos que se anteponen a la realidad, y que la acaban sustituyendo. "Pero una realidad sustituida intencionalmente $[. .$.$] deja de ser lo que es y trastorna$ todo el sentido profundo y vital de la filosofía". ${ }^{24}$

19 Ibídem, p.155.

20 Ibídem, p.157.

21 lbídem.

22 "Filosofía en Centroamérica", Revista de Humanidades, Universidad de El Salvador, Nos. 2-3, 1961, EF I, p. 402.

23 Ibídem.

24 Ibídem. 
La filosofía como forma de vida significa, por tanto, adoptar la actitud radical del filosofar mismo y extenderla "a la totalidad última de la existencia"25, buscando la autoposesión plena de la realidad subjetivada, que de esta manera cobra conciencia de sín $^{26}$. Esto implica, por encima de todo, filosofar a partir del contacto vital del filósofo con las cosas y de los problemas que tienen significado existencial para él o que sean significativos desde un punto de vista humano. La filosofía no es, desde este punto de vista, un mero ejercicio intelectual "extrínsecista", una actividad ajena a la vida del filósofo y a los problemas que enfrenta vitalmente en su situación; o, en otras palabras, un mero ejercicio intelectual "externo" al filósofo, en el que éste sería un mero contemplador "objetivo" de la verdad. La filosofía es el producto de una inteligencia vital en el que la subjetividad del filósofo está involucrada existencialmente con la desvelación y revelación de la realidad que se le hace presente como problema en su propia experiencia vital. Este es el significado primario que Ellacuría le asigna a la función intelectual de la filosofía:

En este punto surge inmediatamente la cuestión de si puede llegar efectivamente la inteligencia a una realidad, por ejemplo Dios, cuando no ha llegado a la vida, prescindiendo aquí de toda implicación sobrenatural refleja. La respuesta es que a una inteligencia vital, no; pero si no es vital, en filosofía al menos, no se puede hablar tampoco de función intelectual en su pleno sentido. ¿Y qué es o puede ser una función intelectual si no alcanza el sentido que le corresponde? Esa realidad debe hacerse presente, ante todo, como problema, sin el que no es posible ni encuentro verdadero ni profundización filosófica, como, a su vez, la presencia de un verdadero problema es ya inicial encuentro y logro filosófico. ${ }^{27}$

Ellacuría introduce este planteamiento para criticar el enfoque escolástico sobre la existencia de Dios. Por más razones que aportemos para probar su existencia, nuestra inteligencia no llegará a Dios, si antes no lo hemos encontrado en nuestra vida como problema. Esto nos da una idea de lo que debe ser la filosofía y la manera en que debe enfrentarse filosóficamente la realidad, si realmente queremos producir conocimiento metafísico con un sentido vital y humano. Se trata de filosofar a partir de los problemas que afectan vitalmente al filósofo, de tal forma que no haya disociación alguna entre el sistema filosófico y la

25 "Introducción a la filosofía", texto introductorio de un curso que dictó en Bilbao en septiembre de 1966, EF I, p.603.

26 Cfr. "Filosofía en Centroamérica”, EF I, p. 402.

27 Ibídem, p.403. 
propia vida, como ocurre en los escolasticismos que "convierten la filosofía en ciencia transmisible y la privan de ser camino del hombre por la verdad a la realidad", y donde "en el mejor de los casos, la mente se pone a la altura de las ideas que se le presentan, pero éstas no aportan su contenido de realidad al hombre, no se interiorizan y vitalizan en él"28.

En la forma escolástica de hacer filosofía la función intelectual se concibe como un mero proceso intelectual, un encadenamiento riguroso de razonamientos, alejado del proceso vital, y en el supuesto de que sólo existe un solo tipo de filosofía y un solo modo de filosofar, válido para todas las épocas y lugares. Para Ellacuría el sentido pleno de la función intelectual sólo se alcanza cuando se orienta hacia la vida. Se filosofa desde la vida y para la vida, en orden a desarrollar y plenificar la vida humana. Y esta es una idea que Ellacuría extenderá a todas las dimensiones de su vida intelectual, como filósofo, teólogo y como analista político. En esto fue consecuente hasta lo último, pues el intelectual Ellacuría llegó a ser asesinado por asumir y defender en su biografía aquello que inspiraba su producción intelectual en todas sus dimensiones ${ }^{29}$.

\section{Filosofía y poesía}

Si bien la idea de la filosofía como forma de vida coincide con la idea zubiriana de la filosofía como resultado de una vida intelectual, y que Ellacuría hará suya posteriormente, en realidad su raíz se encuentra en el modelo de hacer poesía de Ángel Martínez. La concepción de la poesía como una forma de vida es uno de los aspectos que Ellacuría más destaca en el análisis que realiza de la obra de Ángel Martínez y fue uno de los aspectos que tuvo mayor influencia en él. "Estos dos puntos de la poesía, como una nueva forma de vida y de las relaciones que guarda con la filosofía, son transcendentales en la concepción estética del autor, y se palpan a lo largo de toda su producción"30. Es, precisamente, la relación entre poesía y vida lo que llevará a Ellacuría a establecer la conexión entre filosofía y vida:

28 Ibídem, p. 402.

29 En este sentido, Martin Maier señala: "Si analizamos el quehacer teológico de Ignacio Ellacuría [...] en él se da un caso especial de una "biografía existencial teológica", pues el teólogo llegó a ser asesinado por defender en su vida histórica aquello que inspiraba su teología". Martin Maier, "La influencia de Karl Rahner en la teología de Ignacio Ellacuría", Revista Latinoamericana de Teología No. 36, 1996, p.234. En la misma línea, Antonio González destaca que "lo característico de la labor intelectual de Ignacio Ellacuría no consiste tanto en haber puesto la praxis histórica de liberación en el centro de sus reflexiones filosóficas, sino en haber hecho de la filosofía un elemento constitutivo de una existencia dedicada a la liberación". A. González, "Aproximación a la obra filosófica de Ignacio Ellacuría", Revista Estudios Centroamericanos (ECA) Nos.505-506, 1990, p.980.

30 “Ángel Martínez, poeta esencial”, EF I, p.155. 
Respecto del problema de filosofía y vida tuve ante todo el gran consuelo de ver que lo era, pero que también se descubre y se vive su solución de una manera sincera y real [...] he visto su solución radical en aquel "las cosas -siempre las cosas- por sus causas -en su raíz de cosas”. Ciertamente que todo lo demás es esqueleto y ni siquiera eso, sino palabras que resuenan sin sentido como incógnitas de una ecuación sin realidad [...] Claro que para este enfoque de la filosofía -el único verdaderamente filosófico y, en consecuencia, el único genuinamente verdaderohace falta mucha hombría, mucha plenitud de ser en el propio interior, y también mucha sinceridad de ir a las cosas como se debe ir, sin engaños en los que tan voluntariamente caemos porque son fáciles-, mientras que en la verdad y en la vida los caminos son mucho más angostos. ${ }^{31}$

Y por esta orientación esencial, su poesía "es resultado de una forma de ser abierta a todo el ser -y aun a la nada- que quiere encontrar en todo su ser poético y quiere vivirlo todo poéticamente para potenciar al máximo la existencia humana"32. Y esto es justamente lo que le da el carácter vital a su poesía:

La poesía del P. Ángel [...] Pretende decir cosas o, mejor aún, que las cosas se digan a sí mismas de un modo esencial y vital, llegando así a una enorme densidad no solamente conceptual -en la que reside su propio mérito de pensador vital-, sino también en el orden de la imagen, de la insinuación y la anécdota. ${ }^{33}$

En esta línea la captación y posesión del ser de las cosas no se logra ni por abstracción de la realidad concreta y vital, ni por una ideación intelectualista donde se sustituya la realidad existencial de las cosas por ideas y conceptos abstractos. Tampoco supone un empirismo o un sensismo donde se identifica la apariencia sensible de las cosas con su esencia. Es una captación concreta y vital de la esencia viva de lo existente, que supone una actitud y un modo de vida que permiten posesionarse del ser que se manifiesta en la experiencia vital. Se trata, según Ellacuría, de un esfuerzo por

encontrar en cada ser lo esencial de su manifestación sensible, lo que de su figura sensitiva puede desprenderse como significado 
y como símbolo [...] Se viven así las consecuencias de la mejor tradición filosófica, que ve en lo accidental una manifestación de lo esencial; que, principalmente, no confunde el realismo con ninguna de las formas de sensualismo $y$, por tanto, no juzga en ningún momento que las cosas, la realidad profunda y verdadera de las cosas, es sólo -o principalmente siquiera- cual la perciben los sentidos. ${ }^{34}$

Se puede concluir del análisis precedente que Ellacuría extrae su modelo inicial de filosofía del modelo de hacer poesía esencial de Ángel Martínez. La necesidad de producir una palabra eficaz para sí mismo y los demás, exige que esta exprese el ser esencial de las cosas y la profunda unidad entre ellas. En este sentido, la misión del filósofo, al igual que la del poeta, será la de recrear esta visión del mundo, en su vida y en su producción intelectual, y comunicarla a los otros con la pretensión de que éstos la interioricen y puedan así desalienarse y humanizarse en un sentido cristiano. Esto supone que el filósofo haga de la filosofía una forma de vida, comprometiéndose y dedicándose vital y existencialmente a la búsqueda permanente de la verdad más radical de la realidad. Para ello tiene que hacer un esfuerzo de purificación y ascesis de su vida personal, tratando de superar lo "superficial" y "muerto" de la vida cotidiana, "de lo aparente de las mismas cosas que nos aprietan a cada instante" ${ }^{35}$. Si en la cotidianidad lo que predomina es lo "superficial y lo vano", "esas sombras de objetos" que encubren la realidad, el filósofo, al igual que el poeta, "tiene que romper con ese muro que defiende y esconde la verdad mediante ese ahondamiento en el ser, que necesariamente implica una honda penetración y desarrollo de sí mismo"36. Se trata, por tanto, de hacer una filosofía que, parafraseando la propia labor del poeta, sea resultado de una forma de vida abierta al ser, que pretenda encontrar en todo su ser esencial y quiera vivirlo todo filosóficamente para potenciar la existencia humana.

Este tránsito del ámbito poético al ámbito filosófico se justifica, según Ellacuría, por el mismo carácter metafísico de la poesía de Martínez:

[...] en su misma poesía veo dos modos de poesía: una que llamaría psicológica y, otra, metafísica [...] la psicológica me parece que se da cuando el poeta nos dice tan sólo la reacción vital que la realidad produjo en él. La metafísica, que me 
parece más honda y verdadera, es en la que ya no se deja ver la reacción psicológica del poeta, sino aquella por la que el poeta descubre el ser, la realidad viva en sí. ${ }^{37}$

Y este ámbito del ser manifestándose, "pertenece a la filosofía, mientras que la palabra interior más vibrante, viva y manifestativa, es lo propio de la poesía". ${ }^{38}$ Es decir, filosofía y poesía coinciden por ponerse en contacto con las cosas en orden de desvelarlas y revelarlas. La diferencia entre ellas radica en el modo como ejecutan dicha desvelación y revelación del ser: "si se lleva a cabo iluminada y vitalmente por contacto y presencia, por re-creación del objeto que se transmite en la línea misma en que integralmente ha sido posesionado por el poeta, estamos frente a un fenómeno de poesía; y si, por su parte, se lleva a efecto por expresión puramente conceptual, razonada y en un plano de ultimidades, estamos en la esfera de lo filosófico". ${ }^{39}$

\section{La tarea humanizadora de la filosofía}

Este enfoque de la filosofía, de una filosofía vinculada a la vida, con un profundo sentido humanista, que busca la máxima posesión de la verdad para humanizar la propia vida y la de los otros, se explica y se justifica, a los ojos de Ellacuría, por el mundo social e histórico desde el que se pretende hacer filosofía y hacia el cual está dirigida la reflexión filosófica. Este enfoque, pues, supone un diagnóstico y un juicio ético del mundo actual. $Y$ es sobre la base de éstos que Ellacuría define cuál debe ser la filosofía más adecuada en esta circunstancia histórica de la humanidad, y cuáles modelos de filosofía y de filosofar deben desecharse por ser poco heurísticos y poco operativos en función de la humanización y salvación del mundo presente.

En esta época, como ya se señaló, Ellacuría tiene una visión crítica del capitalismo $y$, en general, de la civilización contemporánea, en el que ve el predominio de un "materialismo burgués", de un "materialismo de la abundancia”, que deshumaniza y aliena a los seres humanos de su esencia religiosa, al reducirlos a su ser sensitivo y apariencial, imposibilitándoles así su acceso a lo espiritual y sobrenatural..$^{40} \mathrm{El}$ ser humano ha perdido su capacidad para transcender el mundo y cada vez más se ve arrastrado hacia una vida hecha, caracterizada por el predominio de "apetencias sensitivas, de intereses y gustos mundanos, de

37 Carta de I. Ellacuría a A. Martínez (Ecuador, julio de 1954), EF I, p. 203.

38 Ibídem.

39 “Ángel Martínez, poeta esencial”, EF I, p. 155.

40 Cfr. ibídem, pp. 131-135 (véase también "Bruselas, saldo negativo", EF I, pp. 253 у 263 y

"Marcelino, pan y vino", EF I, p. 113). 
apariencias fáciles". ${ }^{41}$ Es un tipo de vida naturalizada y maquinizada, que no tiene nada de "invención autónoma, de deseo original y personal, de proceso creador". ${ }^{42}$ Los individuos se enfrentan al mundo de una manera superficial y despersonalizada por cuanto en "la vida de cada uno casi todo procede predeterminadamente, o de factores biológicos y psicológicos necesitantes, 0 de incitaciones exteriores que dejan sin actuación auténtica a nuestra libertad: se carece de intimidad, de reclusión meditativa y solitaria dentro de sí y, por lo tanto, de mismidad". ${ }^{43}$

En consecuencia, “los hombres no son mejores ni más grandes ni más felices, aunque, quizá, se encuentren más entretenidos”. ${ }^{44} \mathrm{El}$ desarrollo tecnológico y el bienestar material han empequeñecido al hombre en la misma medida que han crecido sus recursos mecánicos. El ser humano se ha deshumanizado "por la habituación a cosas de siempre sabidas que le dan seguridad, por la protección superficial recibida de manos extrañas, que ya le es imposible enfrentarse desnudo y solitario frente a lo desconocido e imprevisto. Más aún, se ha empobrecido tanto en lo interior por la agitación de su vida falsamente excitada desde fuera, que ya le es imposible vivir quieto y a solas, porque su vivienda personal está vacía- ya no sólo para descansar, aun para vivir necesitamos entretenernos con lo que viene de fuera". ${ }^{45}$ Es una situación donde la técnica ha perdido su radicación en la vida humana y tiende a solidificarse, a distanciarse más y más de lo auténticamente humano:

La técnica que nació para facilitar la vida humana va convirtiéndose, por su propia dinámica, en elemento productor de unas exigencias nuevas, que ya no nacen de dentro del hombre y que, por tanto, dejan de ser vitales y humanas [...]. Que los fabricantes susciten con su propaganda las necesidades y los deseos, muestra cuán empobrecido ha quedado el hombre

41 “Sobre la irreligiosidad", manuscrito redactado en Innsbruck en 1959, EF I, p. 276.

42 "Técnica y vida humana en Ortega y Gasset: Estudio de Meditación de la técnica", manuscrito redactado en Innsbruck entre marzo y mayor de 1961, EF I, p. 507.

43 "Sobre la irreligiosidad", EF I, p. 276.

44 "Ángel Martínez, poeta esencial”, EF I, p. 132. En su artículo "Utopía y profetismo desde América Latina", de 1989, Ellacuría emplea esta misma idea para criticar el modelo de ser humano que promueve la civilización del capital: "el orden cultural consumista es un producto del orden económico consumista... No es por el camino del cambio permanente de entretenimientos como se va engrandecer el acervo cultural. Confundir el ser feliz con el estar entretenido, favorece y promueve el producto consumista a través de necesidades inducidas por la vía del mercadeo, pero al mismo tiempo, descubre y fomenta el mayor de los vacíos interiores", en "Utopía y profetismo desde América Latina”, Revista Latinoamericana de teología (17), 1989, p.180.

45 Ibídem, p. 133. 
en su facultad de desearse y ser él mismo, y cómo tiende la técnica a hacer vivir desde fuera, es decir, a ser cosa muerta. ${ }^{46}$

Este predominio desmedido de lo técnico es uno de los factores principales que inciden en la irreligiosidad del ser humano actual, en lo que Ellacuría llama "ateísmo de la vida", que consiste en "la negación en la vida de la existencia de Dios", es decir, de "una vida que se desarrolla en todas sus manifestaciones ignorando absolutamente lo que Dios es en sí y, sobre todo, respecto de ella". ${ }^{47}$ Así, la irreligiosidad del hombre actual se agudiza porque el mundo en el que necesariamente tiene que hacer su vida es hoy especialmente irreligioso, debido a su doble característica de "superficialidad" y “alteración":

Nuestra época está llena de dos clases de hombres: unos masificados, que no operan sino conforme a los estímulos de fuera $y$, otros, psicológicamente tarados, inseguros de sí mismos, clientes potenciales de alienistas y psiquiatras, cuyas reacciones de altivez, de falsa energía frente a los que creen débiles, no son sino movimientos de náufragos para sobrenadar en un medio en el que son incapaces de sostenerse por la sencilla afirmación de un ser auténticamente desarrollado. ${ }^{48}$

La situación de irreligiosidad predominante agrava aún más la alienación del ser humano por cuanto le refuerza el extrañamiento de su ser esencial y verdadero y le oscurece el carácter transcendente de su realización personal, lo que provoca que permanezca en una vida "levantada sobre la negación y la muerte de nuestro ser auténtico". ${ }^{49}$ En este sentido, la irreligiosidad contemporánea es al mismo tiempo reflejo y causa de la alienación que manifiesta el ser humano en su existencia histórica actual: es reflejo, por cuanto es expresión de un tipo de vida superficial y cosificado; pero, a su vez, es causa, porque la irreligiosidad, cuyas raíces no derivan sólo de la situación histórica del mundo sino también de la propia situación original y personal del existente humano, justifica, reproduce y universaliza el tipo de vida alienada que llevan los seres humanos.

De cara a esta situación, la filosofía se hace necesaria para "despertar el alma de los hombres" y orientarlos "hacia lo que constituye la vida verdadera, el ser auténtico del hombre, sin dejarse engañar por anuncios de colores o

46 "Técnica y vida humana en Ortega y Gasset", EF I, p. 507.

47 "Sobre la irreligiosidad", EF I, p. 272.

48 Ibídem, p. 278.

49 Ibídem, p. 277. 
encendidas apariencias". ${ }^{50}$ Ahora bien, no se trata de proponer "utópicamente una imposible vuelta a la negación de todo lo mecánico, sino de la superación de lo puramente corporal por la vivificación y exaltación del espíritu". ${ }^{51}$ Se trata, por tanto, de proponer el paso de la vida falsa a la vida auténtica: "la vida falsa y la vida auténtica no son dos formas diversas de una misma vida, sino que son dos cosas esencialmente distintas: frente a los escaparates, la reconcentrada verdad de un ser escondido, pero operante". ${ }^{52}$ Y el filósofo debe "mostrar el paso a la verdadera vida, por la muerte de la falsa" mediante el logro de una interpretación esencial del ser humano que sea operativa en la consecución de ese fin. El fin es posibilitar la superación de esta situación de alienación levantada sobre la negación y muerte de nuestro ser auténtico mediante la recuperación del sentido religioso de la vida humana. Desde esta óptica, la tarea ética de la filosofía consiste, según Ellacuría, en “libertar el alma de esta civilización atenazada por un superdesarrollo de lo superficial y lo material, de lo presente y vistoso, de lo accesorio y pasajero, de la prisa y las vueltas a lo mismo sin ningún avance positivo". ${ }^{53}$

\section{La revitalización del tomismo}

A partir de estos presupuestos, se entiende mejor el intento de Ellacuría por sintetizar lo clásico y lo moderno en orden a "estructurar una cabal filosofía integradora, en verdad, perenne", ${ }^{54}$ que aliente e ilumine el proceso de desalienación y humanización del hombre actual. Se puede decir que Ellacuría busca sentar las bases para formular un auténtico humanismo cristiano que llene los vacíos e insuficiencias de la escolástica en cuanto pensamiento abstracto, desencarnado y alejado de los problemas humanos concretos.

Congruente con este esfuerzo, Ellacuría considera necesario partir de una filosofía cristiana como la desarrollada por santo Tomás, pero corregida vital y existencialmente por lo mejor de la filosofía contemporánea, especialmente por las filosofías vitalistas y existencialistas en boga, concretamente, por el raciovitalismo de Ortega y Gasset. En concreto, se trata de realizar una síntesis o conciliación entre la filosofía escolástica y la filosofía vitalista moderna, cuyo propósito primario sea renovar y actualizar la filosofía tomista con el fin de hacerla plenamente conciliable con el cristianismo, al enderezarla hacia la resolución del problema vital y existencial del ser humano en la civilización contemporánea:

50 “Ángel Martínez, poeta esencial”, EF I, p. 135.

51 Ibídem, p. 136.

52 Ibídem, p. 137.

53 Ibídem, p. 140.

54 “El despertar de la filosofía”, Revista Cultura, No. 11, 1956, San Salvador, EF I, p. 48. 
¿Por qué no se va a poder dar un recto sentido a la reducción de la filosofía a la vida más allá del sentido sustentado por el tomismo? ¿Ni se ve por qué no se pueda afirmar nada más profundo ni más serio como origen del filosofar que la admiración, porque así lo dicen Aristóteles y santo Tomás o a eso empujase el univocismo de la esencia humana? ${ }^{55}$

Es un esfuerzo de síntesis o de conciliación que está motivado primariamente, pues, por razones prácticas y vitales, urgido -como afirma el mismo Ellacuríapor una necesidad vital de marcado carácter intelectual, por cuanto busca dar con la verdad para saber y así orientar y dirigir la vida humana:

A la filosofía, en efecto, se llega cuando se va a ella auténticamente por una necesidad vital de marcado carácter intelectual. En esto convienen unos y otros: porque sea el inicio de la filosofía la admiración como quieren los aristotélicos y platónicos; sea la angustia de quedarse a la deriva sin suficiente luz y seguridad para orientarse en la vida, según los existencialistas; en ambos casos nos encontramos ante una necesidad vital de profundo carácter intelectual: necesidad vital, porque es todo el hombre quien se siente impelido por una inquietud que le desasosiega y le urge por entero; de carácter intelectual, porque trata de formular ideológica y sistemáticamente una concepción del mundo, porque trata de investigar intelectualmente las cosas como son, de tener dentro claro lo que fuera está escondido, lo que a los demás se les ofrece superficial y oscuro. ${ }^{56}$

\subsection{El tomismo como fundamento de un auténtico humanismo}

En este esfuerzo es importante destacar la valoración que Ellacuría hace de santo Tomás. Ellacuría escribió sobre él con el fin de mostrar el núcleo tomista rescatable para construir una visión más existencial y humanista del mundo, haciendo más efectivo el tomismo en nuestro tiempo ${ }^{57}$. Para Ellacuría santo Tomás representa el modelo de intelectual cristiano, válido para la época actual, capaz de sintetizar la fe y la razón, la filosofía y la teología, lo profano y lo religioso, la naturaleza y la gracia, el humanismo y el cristianismo en

55 "Posibilidad y modo de aproximación entre la filosofía escolástica y la filosofía vitalista moderna", EF I, p. 243.

56 "El despertar de la filosofía”, EF I, p. 50.

57 “Tomás de Aquino, intelectual católico", ECA, No., 146, 1960, EF I, p.329. 
función de "encontrar y fundamentar esencialmente esa verdad que hará libre y personal al hombre". ${ }^{58}$

Ellacuría destaca, en primer lugar, su modo de filosofar y su talante filosófico de tipo esencialista y universalista, "anclado decisivamente en lo profundo y radical, sin concesiones a los reclamos de superficialidades o accidentalismos" ${ }^{59}$. En segundo lugar, Ellacuría resalta su "ascetismo religioso" como condición para la persecución de la verdad total de las cosas y su intento por inteligirlas y explicarlas a través del contacto sumiso y activo con la realidad ${ }^{60}$. En tercer lugar, Ellacuría se refiere a los tres principios cristianos que definen la personalidad intelectual del aquinate: amor a la verdad, necesidad de profundidad esencial y repudio de toda forma de maniqueísmo. El ansia de verdad como principio de una vida intelectual lleva a ésta a un dinamismo esencialmente positivo y creador, que consiste en ir más a las cosas que a los conceptos o los dogmas y en profundizar en todo, en busca de "la última y total profundidad"61.

Además, su rechazo del maniqueísmo se expresa en una libertad de prejuicios absoluta, que le da una amplitud mental para asumir "todas las briznas de luz que la mente humana ha irradiado sea de donde sea, y sea por quien sea" 62 . En este sentido, la recreación y revitalización de la metafísica aristotélica ejemplifican una cualidad notable de un intelectual cristiano: su rechazo a la ortodoxia y su "positivismo salvador de recoger todo lo que de bueno se encuentre, valorándolo en la mejor de sus direcciones posibles. ¿Qué hubiera sido de Aristóteles en manos de los negros celadores de la ortodoxia? Tal vez hubiera quedado repudiado para siempre, si hubieran prevalecido los negativistas que se ensañaban con sus discrepancias del dogma y la rutina"63.

Para Ellacuría estos son elementos valiosos para fundamentar un humanismo cristiano válido para el mundo actual. Pero esto pasa por entender adecuadamente la actitud personal de santo Tomás, sumergiéndonos en su mundo, para después traerlo al nuestro. Es decir, "síntesis nueva de lo permanente con la forma de nuestro tiempo" 64 . Esto no lo han realizado sus seguidores y comentaristas que se han dedicado a transmitir mecánicamente su doctrina, abstrayéndola de la realidad concreta, "sin llegar a la penetración ontológica de la realidad,

58 Ibídem.

59 “Santo Tomás, hombre de su siglo", ECA, No. 135, 1959, EF I, p.217.

60 Ibídem, p.219.

61 “Tomás de Aquino, intelectual católico”, EF I, p.331.

62 Ibídem, p. 332.

63 Ibídem, p. 335.

64 “El tomismo, ¿es un humanismo?”, ECA, No. 157, 1961, EF I, p. 392. 
ni mucho menos a la captación de su significado vital" 65 . Se ha desvirtuado la naturaleza escolar de su obra, no se ha captado su mundo propio y se ha interpretado inadecuadamente su angelismo, dando pie a la acusación de desprecio y aniquilación de lo humano, que ha sido la objeción histórica que se le ha imputado a la doctrina tomista. De hecho, algunos pensadores escolásticos han consumado una "verdadera deshumanización" de la obra tomista y se han vuelto incapaces de "presentarse como auténticos representantes del mundo actual" ${ }^{66}$.

\subsection{Ortega: intelectual de la vida}

Hay que destacar aquí la valoración que Ellacuría hace de Ortega y Gasset, en cuanto representante de la filosofía vitalista moderna. El conocimiento de Ellacuría sobre el pensamiento de Ortega se inició en los años que estudió en Quito y se consolidó inmediatamente después, en San Salvador, donde realizó un estudio de su obra para escribir un artículo sobre su filosofía:

Me pidió el P. Garrido un Artículo para ECA y, aunque ya tenía algún conocimiento de Ortega, pues había leído bastante de sus obras principales, me decidí a meterme de bruces en él, intentando ponerme un poco claro sobre un caso tan discutido. La disparidad de juicios entre sus críticos y sus amigos, la eficacia de su obra en tantos hombres de España y de América, me tentaba a investigar la realidad de su obra y la explicación de ese resultado tan dispar que su obra ha producido. ${ }^{67}$

Frente a la actitud negativa y destructora de la obra de Ortega de parte de algunos autores escolásticos, Ellacuría busca en su estudio valorar "todo lo bueno, que es el único modo de entender, de superarlo y de amenguar el posible daño. Este ha sido mayor porque no se ha profundizado en Ortega hasta allí donde se ven sus logros y sus fallos"68. Desde esta óptica, Ellacuría considera necesario introducirse, de la mano de Ortega, en el mundo cultural contemporáneo para buscar transformarlo y humanizarlo en un sentido cristiano. “Es preferible padecer el escándalo de algún escrupuloso que, permaneciendo

65 Ibídem, p.390.

66 Ibídem, p.392.

67 Carta de I. Ellacuría a A. Martínez (San Salvador, 11 de febrero de 1956), EF I, p.212

68 Ibídem, p. 213. Aquí Ellacuría tiene presente la polémica que hubo en España en esta época en torno a la obra de Ortega, especialmente con grandes detractores nacional-católicos como el p. Santiago Ramírez, un dominico que había editado la obra de santo Tomás, y los simpatizantes de Ortega, entre los cuales se encontraba Julián Marías, quien salió a defender públicamente a Ortega frente a las críticas de Ramírez. Cfr. S. Ramírez, La filosofía de Ortega y Gasset, Barcelona, 1958. 
inactivo o, simplemente, obtuso a la comprensión, dejar que se nos escape de las manos este mundo cultural que, por exigencia de su constitución y de su historia particular, debe ser cristiano"69.

En este esfuerzo, no se trata de asumir todo lo que Ortega ha planteado ni de tener por bueno todo lo afirmado por él; se trata de asumirlo, apreciando sus valores y ponderando, a la vez, sus "deficiencias radicadas en la proclividad de sus escritos hacia un relativismo filosófico y hacia un humanismo laico, descristianizado y antropocentrista"70. En este sentido, Ortega, según Ellacuría,

no es maestro perfecto por su misma contextura psicológica, como por la circunstancia cultural que le tocó vivir, que coartaron muchas de las dimensiones que un pensador y un filósofo deben poseer en cuanto dedicación, concentración y profundidad, rigor y sistema. No lo es, en fin, porque su cerrazón a los horizontes religiosos le escamoteó muchas soluciones, decisivas soluciones, más aún, muchos y decisivos datos del problema humano tanto individual como social e histórico, aun beneficiándose en su educación y en enfoques posteriores de los valores culturales del cristianismo. ${ }^{71}$

La valoración y entendimiento adecuados del pensamiento de Ortega exige que se le estudie “desde dentro", adentrándose en su vida y en su obra. Esto que es válido para la comprensión de cualquier pensador, es más pertinente en el caso de Ortega y su obra, "tan entreverada con la trayectoria de su vida, preocupada de ser sí misma, actualísima y circunstancial, original y distinta, referida al yo y a la circunstancia, primeramente al yo que Ortega era y a la circunstancia que personalmente le oprimía"72.

En efecto, la razón vital y la razón histórica orteguianas son fundamentalmente una indagación en las profundidades de la propia vida, formuladas luego lo más vitalmente posible, y cuya comprobación se reduce a pedir a los demás que comparen sus propias vivencias e intimidades para calibrar y apreciar las realidades iluminadas por él. Esta característica y este estilo de proceder sobre su propia vida, "sobre lo más vivido del yo y sobre lo más punzante de la actualidad circunstante"73, trae consigo una serie de logros y virtudes,

\footnotetext{
69 “Ortega y Gasset: hombre de nuestro ayer”, EFI, p.20

70 Ibídem.

71 Ibídem, p. 22.

72 “Ortega y Gasset desde dentro", ECA, No. 105, 1956, EF I, p. 27.

73 Ibídem, p. 30.
} 
por encima de lo practicado por el escolasticismo más ortodoxo: contacto inmediato con la realidad, actualidad, vitalismo, intuiciones de contenido rico y denso, presencia de realidades humanas. Todo esto le lleva a la constitución de un pensar sólido, de gran contenido vital y humano, en el que las ideas "son signos vivientes de lo que cada uno lleva consigo, aun sin percatarse de ello". ${ }^{74}$

En esta línea Ellacuría resalta un aspecto de la filosofía de Ortega, que coincide con lo que ya había asimilado de los magisterios de Aurelio Espinosa y de Ángel Martínez: su "preocupación radical por la vida y la cultura, junto con los problemas que su necesaria unión plantean" y en la que "el elemento primero y fundamental es la vida"75. La importancia de esta tesis es que lleva a postular como obligación ética fundamental el acrecentamiento de la vida "sin sometimiento alguno a norma distinta de la misma vida", y a valorar toda norma o institución en función de la vida: "si favorece el desarrollo de ella será aceptada; si, al contrario, pone trabas al impulso vital, será rechazada como inauténtica y perniciosa"76.

Este principio repercute también en la orientación ética que debe dársele a la vida intelectual en función de construir una cultura de la vida y para la vida, y que le permite a Ellacuría criticar el modelo de filósofo escolástico y, a la vez, exponer su visión de lo que debe ser la función del filósofo en el mundo actual:

[Ortega] repudió para sí todo carácter de especialismo estrecho, de sabio que, prisionero de la teoría muerta, no sabe nada de la vida. Antes que ser profesional o investigador, quiso ser hombre. Ortega, profesión: hombre. Porque si son necesarios los especialistas que investiguen un campo estrechamente acotado, lo son mucho más, ante todo para dirigir este mundo en crisis, los hombres poderosamente vitales, con un sistema cultural completo y vivo desde el que puedan enfrentarse, con verdad, al mundo de hoy. ${ }^{77}$

Estas afirmaciones nos ilustran el tipo de intelectual y de filósofo que Ellacuría pretende ser en este momento y que no encuentra en los moldes del escolasticismo ortodoxo: filosofar para construir una cultura para la vida, con función vitalizadora y humanizadora; una cultura que brinde "seguridad y luz con un sistema vital de ideas que traiga y lleve un mensaje penetrante y cálido 
del mundo al yo y del yo al mundo". ${ }^{78}$ En este sentido, es mérito de Ortega, a los ojos de Ellacuría, que

trató de evitar el pecado que ha desvinculado al mundo presente del intelectual: el haberse dedicado a una cultura de ideas, el haber trabajado por una cultura erudita e ineficaz para la vida y no por una cultura humana que potenciase la vida. Él, al contrario, será intelectual de la vida y para ella, con afán de proselitismo, para hacer de el Otro, el ser alterado sin interioridad, un nuevo ser adentrado en sí, ensimismado, que goza de aquella plenitud que el mundo no abre, sino al intelectual que, por serlo, contempla transfigurado todas las cosas. $^{79}$

Pero lo que Ortega gana en vitalismo lo pierde en superficialidad e incontinuidad, "quedando mancos sus esfuerzos filosóficos". ${ }^{80} \mathrm{El}$ problema es que Ortega no explica adecuadamente las realidades "derivadas y contingentes" desde las realidades y principios metafísicos que las fundamentan. Y es que "si no se investiga, sino lo que se vive y mientras se vive, no tendrá el pensamiento aquel carácter de ultimidad y sistematización definitiva que exige la filosofía. En Ortega, de hecho, faltan esos temas últimos y en el modo de desarrollar los elegidos por él se echan de menos, ordinariamente, la seriedad, plenitud y profundidad que de sus capacidades filosóficas se podían esperar" ${ }^{81}$.

En la obra de Ortega, según Ellacuría, se refleja una especie de "inautenticidad ontológica" propia de las vidas que pretenden vivir con seriedad y plenitud, aunque no en un plano de absoluta verdad objetiva, y que es paralela a la inautenticidad psicológica, propia de las vidas superficiales que viven "en la cosificación dispersa de una vida desvivida por las cosas" no ha "superado el ensimismamiento de la propia vida" y no ha "alcanzado, por tanto, la dimensión ontológica de la religación ni la subjetivización religiosa que es su correlato de vida" ${ }^{33}$. En él se expresa una vida "que se la vive con las propias fuerzas sin fin distinto que ella misma; se la vive con radical confianza en esas propias fuerzas que la van haciendo, con lo que adquiere un carácter

78 Ibídem.

79 Ibídem, p. 42.

80 Ibídem, p. 40.

81 lbídem.

82 "Ortega, existencia desligada", manuscrito redactado en Innsbruck, a finales de 1958, EF I, p. 268.

83 Ibídem. 
absolutamente absoluto que de ninguna manera le compete: es la soberbia de la vida por la que el hombre se fundamenta a sí mismo". ${ }^{84}$

Estas críticas no impiden que Ellacuría valore positivamente la fenomenología orteguiana como método de acceso para captar la realidad humana a partir de lo que los seres humanos concretos manifiestan en las situaciones cotidianas en las que están inmersos. Frente al método escolástico que enfoca el estudio del ser humano abstraído de toda situación y que le da, por tanto, primacía a los métodos deductivos frente a los inductivos o intuitivos,

Ortega está persuadido de que no es la línea recta deductiva el camino más corto entre dos extremos humanos, pues las realidades humanas no están distantes, sino presentes, aunque enigmáticas y escondidas; que es menester ir bien cargado de realidades para que la visión de lo que es realidad sea efectivamente real, sin lo cual no es posible la filosofía ni aun el verdadero conocimiento, por lo menos respecto de aquellos entes que respecto al hombre pueden entrar en contacto inmediato, en presencia existencial. ${ }^{85}$

En realidad, para Ellacuría la fenomenología orteguiana no se diferencia mucho del sentido que Heidegger da a la fenomenología. Ambas comparten lo común a toda fenomenología que consiste en ir "a las cosas mismas" buscando desvelar lo que está oculto en aquello que se muestra, esto es, el sentido y fundamento de lo que aparece, del fenómeno. La diferencia de Ortega con Heidegger radica en que aquél no pretende construir una ontología general, sino "mostrar el ser del hombre histórico". El supuesto orteguiano es que "es imposible entender filosóficamente el ser del hombre histórico, que es a su vez un ser histórico aun en cuanto ser, sin arrancar fenomenológicamente de su mostrarse como es y no como pudo ser en abstracto". ${ }^{86}$

De esta manera, la fenomenología en Ortega se convierte en razón histórica por cuanto el ser que pretende mostrar es constitutivamente histórico. El método fenomenológico no consiste en "contar cuentos, aportar datos y garantizar detalles, sino mostrar el hacerse de aquellas cosas que son lo que son haciéndose, que están en perpetuo status nascendi". ${ }^{87}$ Es un método estrictamente filosófico, porque el proceso de descubrir las cosas en su 
hacerse no se reduce a indicar el proceso empírico de su origen, sino revelar los supuestos más radicales de ellas, que son precisamente los más ocultos y los que suelen pasar desapercibidos. Este modo de entender el método fenomenológico representa una superación del idealismo que subyace en la fenomenología de Husserl por cuanto ésta supone una "contemplación que desexistencializa, des-vitaliza y des-yoiza”. Por ello, sin abandonar la exigencia de necesidad esencial propia del pensamiento husserliano, “Ortega pretende realmente, sobre todo al tratar de cosas humanas, que la realidad se presente como es, vale decir, ejecutivamente, pero sin olvidar que el filósofo no puede perderse en explicaciones meramente fácticas". ${ }^{88}$

La utilización de estos métodos por parte de Ortega se explica por el significado que adquiere en su obra la "razón vital", que supone un nuevo concepto de realidad y un nuevo concepto de filosofía. Frente a naturalismos e idealismos, Ellacuría señala que

\begin{abstract}
Ortega necesita salvar ambos extremos en los que frecuentemente se han "extremado" las corrientes filosóficas de todos los tiempos. Esto supone que necesita traer a su pensamiento la realidad en su máxima riqueza para que no deje de ser precisamente realidad, sino mero fantasma de sí misma, pero, a la vez, encontrando la dimensión precisa en que esa realidad cobra su logos, su verdadero sentido intelectual, sin el que tal vez fuera cosa, momento vital, pero no realidad, ente que es como es. ${ }^{89}$
\end{abstract}

Según Ellacuría, la lección que se puede sacar de este planteamiento de Ortega para la filosofía es que si se pretende hacer una filosofía que sea, a la vez, razonable y vital, necesaria y real, "se precisa acercarse a la realidad de aquel modo preciso en que ésta abra todo su secreto, de manera que no se la deforme al buscar en ella su efectivo nivel filosófico". ${ }^{90}$ Buscar la máxima posesión de la realidad a través del contacto directo, preconceptual y fenomenológico con las realidades concretas, es una característica que Ellacuría asume del método orteguiano como método válido para hacer una filosofía sólida y actual, con contenido real y humano, a diferencia del método escolástico, caracterizado por su excesivo intelectualismo y su orientación hacia la abstracción y la deducción, y de poco contenido vital. 
Hay que notar que esta preferencia por el contacto directo con las cosas, como primer momento del acceso filosófico a la realidad, es una dimensión que Ellacuría ya había asimilado del poeta Ángel Martínez, como un elemento esencial para hacer de la filosofía una forma de vida, según lo apuntamos antes. Para Ellacuría, tanto en la poesía de Ángel Martínez como en la filosofía de Ortega, "el fin será que el objeto se interiorice en el sujeto, pero para ello no hay otro medio efectivo que lograr la penetración efectiva del sujeto en la realidad, anteriormente a su posible desfiguración como objeto". ${ }^{91}$ Esto significa una nueva forma de realismo que supera el realismo que sustentan los pensadores escolásticos e, incluso, de un realismo más consecuente con el viejo principio clásico "de que no hay nada en el pensamiento que no haya comenzado por los sentidos”. Y es que, a diferencia del método escolástico, aquí, según Ellacuría,

el postulado fundamental siempre operante, al que todo se subordina, es que se precisa el contacto con la realidad y no con sustitutivos, un contacto que muchas veces exigirá un nivel sensitivo que nunca, claro está, puede ser en el hombre meramente tal. En otras ocasiones exigirá un paso hacia el campo empírico en busca de la reconstrucción psicológicamente presumible de un efectivo proceder [...]. Más allá será la constatación con otras realidades similares en su contraste con lo diferenciativo, de lo que es específicamente humano [...] donde no se parte de una noción previa para deducir desde ella lo que puede ser específico del hombre a diferencia del animal, sino de la penetración en la doble realidad que representan trascendiendo las diferencias empíricas [...] para dar con la condición ontológica existencial del hombre, que se nos descubre como inesperadamente una vez atravesados los velos. ${ }^{92}$

Ellacuría no abandonará esta orientación realista en su filosofía posterior, una orientación que encontrará su pleno desarrollo cuando, más tarde, Ellacuría adopte el realismo zubiriano basado en la inteligencia sentiente. En estos momentos está convencido, por el impacto del método fenomenológico orteguiano, de que 
la razón, si de verdad quiere ser lo que es, no puede eludir el contacto con la realidad [...] es la realidad la que tiene que dársenos, aunque no lo hará en realidad de verdad, sino respecto de un espectador dinámico que vaya actualizando en sí las diferentes perspectivas en que la realidad también consiste. Y esto dentro de las directrices de un método fenomenológico purificado de sus posibles desviaciones idealistas por el carácter ejecutivo de todo lo que es vital. ${ }^{93}$

Ahora bien, para Ellacuría el método fenomenológico sólo es válido como un primer momento en el acceso filosófico a la realidad, pero no lo agota. Si bien el análisis fenomenológico nos da un acceso primario a la realidad, es necesario superar este nivel para alcanzar los estratos más radicales y últimos. Esta superación consistirá en un proceso estrictamente racional que permita transcender el ámbito del "ser para nosotros", determinado por el análisis fenomenológico de las realidades que se nos presentan en nuestra experiencia vital, hacia el ámbito del "ser en sí" de las mismas, que sería el propiamente metafísico. Se trata de pasar de la realidad tal y como es percibida y vivida por nosotros a la realidad tal y como es en sí de las cosas.

La razón principal que Ellacuría aduce para ello es que las realidades presentes en la propia vida tienen distinta proximidad ontológica y psicológica respecto a ella, por lo

que la condición iluminadora de mi vida es muy distinta respecto de una realidades que otras. Por consiguiente, el método apto para desentrañar, desde su apariencia en mi vida, su hipotética realidad en sí debe ser muy distinto. La distinción estará condicionada tanto por la forma de su presencia en mi vida como por la naturaleza prevista en mi vida de la realidad en cuestión tal como es en sí. Esto implica, a su vez, que si el método fenomenológico es el comienzo indispensable para descubrir lo que las realidades anuncian en mi vida, tiene que ser superado para pasar del "ser para" de las cosas a su realidad en sí. ${ }^{94}$

Para ilustrar esta posición se puede decir que una cosa es el análisis de las cosas reales tal y como se nos dan en nuestra percepción y otra es la construcción de

93 Ibídem, pp. 436-437. Cfr. J. Ortega y Gasset, "Creencia y verdad”, en La idea de principio en Leibniz y la evolución de la teoría deductiva, Buenos Aires, 1958, p. 349.

94 Ibídem, p.484. 
una teoría metafísica que pretenda decirnos qué son ellas en sí mismas allende del campo real percibido. Ellacuría no ve contradicción entre los dos niveles de conocimiento sino complementariedad. El análisis fenomenológico una vez que nos ha posibilitado el acceso a la realidad y nos ha permitido determinar críticamente de qué realidad se trata, no excluye el esfuerzo racional de buscar su fundamento, aunque con la conciencia de que ese esfuerzo es una búsqueda abierta y, por tanto, histórica.

\section{3. La conciliación jerárquica entre la escolástica y el vitalismo}

En su proyecto de conciliación, Ellacuría propone realizar una conciliación jerárquica, que consiste en una superación de las posturas encontradas de las dos corrientes, pero sobre la "base fundamentalmente apta e imprescindible de la filosofía perenne" 95 . No se trata, por tanto, de realizar un eclecticismo sin jerarquía, sino de una ampliación de campos a partir de lo ya logrado por la filosofía tomista. En otras palabras, no se trata de abandonar el tomismo para hacerse vitalista, sino de potenciar la propia filosofía tomista con el fin de hacerla más eficaz en la búsqueda de soluciones teóricas y prácticas a los problemas del mundo contemporáneo. En este sentido, Ellacuría busca vitalizar el tomismo, encarnarlo vitalmente:

[...] el tomismo no debe aspirar tan sólo a revivir el santo Tomás medieval, sino que su misión específica es traerlo a la altura del propio tiempo, revivirlo, pero con la modulación característica del propio mundo. ${ }^{96}$

Es una posición de conciliación y complementariedad que busca solidificar lo moderno y ampliar y humanizar lo antiguo, y que específicamente se traduce en el intento de dotar de una sólida base metafísica a la realidad asegurada por Ortega y de vitalizar y humanizar la realidad presentada por el pensamiento aristotélico-tomista. ${ }^{97} \mathrm{Si}$ al vitalismo le falta un sólido fundamento metafísico, al tomismo le falta un complemento vital, contacto inmediato con la realidad humana tal como es:

Cualquier pensador vital siente que en las fórmulas clásicas se escapa lo existente y se difumina el problema particular; esa

\footnotetext{
95 "Posibilidad y modo de aproximación entre la filosofía escolástica y la filosofía vitalista moderna", EF I, p. 244.

96 "El tomismo, ¿es un humanismo?", EF I, p. 388.

$97 \mathrm{Cfr}$. "Posibilidad y modo de aproximación entre la filosofía escolástica y la filosofía vitalista moderna", EF I, p. 245.
} 
distancia entre la naturaleza universal, unívoca para todos, y la realidad concreta bien diferenciada aun dentro de sus marcos generales, la realidad humana con su peculiar y próximo vivir, puede ser salvada hasta cierto punto por los análisis preñados de contenido vital con que los modernos logran poner en contacto a sus lectores con la vida tal como es y se vive. ${ }^{98}$

Los elementos de la filosofía perenne que pueden ayudar a esta integración superadora, según Ellacuría, se reducen a dos: "una gran potencia de procedimiento lógico, crítico y sistemático, y un sistema amplio que enfoca decisiva y aceptablemente muchos de los problemas capitales y básicos de la naturaleza y la esencia de las cosas"99. Los filósofos escolásticos, a su vez, si pretenden perfeccionar la filosofía perenne, deben procurar un "espíritu efectivamente abierto que no se comporte prácticamente como si la escolástica no tuviese defecto alguno", y deben acomodarse a lo actual, “dejando accidentalidades propias de tiempos pasados". En este sentido, lo importante es que hagan "un esfuerzo por ir a la realidad misma como medida de intelección del sistema para que aquélla configure a éste, y no sea éste quien desfigure a aquélla e impida un real acercamiento y posesión de la vida humana"100. El problema es que estos filósofos han convertido el tomismo en "un tomismo intemporal y repetitorio, es decir, un tomismo que ni siquiera reproduce el valor filosófico de su origen, sino tan sólo la inteligencia de sus fórmulas"101. De hecho, "ni el tomismo ni el suarecianismo, en cuanto son dos sistemas contrapuestos y en cuanto se presentan como dos intentos de devorarse mutuamente en una interminable discusión dialéctica, no tienen mucho que hacer en el campo de una auténtica filosofía"102.

Sin embargo, la obra realizada por el neotomismo alemán es notable por cuanto ha abandonado ese nivel de planteamiento dialéctico para abrirse a las nuevas filosofías que han enriquecido el pensamiento filosófico, desde Kant hasta nuestros días. Los autores de esta corriente, según Ellacuría, ya no tratan "de buscar comprobaciones nuevas al esquema perfecto ya poseído, sino de enriquecer el mismo esquema, de abrirlo e inyectarle nueva vida"103. Sus obras, "constituyen un conjunto de libros verdaderamente filosóficos, abiertos al pensamiento contemporáneo, muy influidos por éste, sin perder por ello ninguna de las tesis tomistas fundamentales ni la radical actitud de santo Tomás

98 Ibídem, pp.246-247.

99 Ibídem, p. 249.

100 Ibídem.

101 "Filosofía en Centroamérica”, EF I, p.404-405.

102 Ibídem, p. 405.

103 Ibídem. Aquí Ellacuría se refiere expresamente a K. Rahner, E. Coreth y Lotz. 
ante la realidad"104. Lo destacable es que ya no consideran "el tomismo como algo perfectamente acabado, al que no le queda sino transmitirse y defenderse - las más de las veces atacando lo que no se entiende- sino más bien como un esfuerzo filosófico para reconquistar en nuestro tiempo una realidad cada vez más múltiple. Pero un esfuerzo filosófico actual, lo cual ineludiblemente importa pensar -como forma de pensamiento, como preocupación, como objetos del pensamiento- como hoy se piensa". ${ }^{105}$

Por este camino, piensa Ellacuría, se podrá potenciar a la filosofía y se hará un bien al ser humano de hoy:

Si todavía no ha aparecido en el campo del pensamiento quien integre lo que en el discurrir de muchos siglos han dejado de aceptable tantos filósofos, bueno fuera que se preparara su advenimiento y la posibilidad de su obra con una actitud abierta y con logros parciales respecto a algunas conciliaciones y superaciones más obvias. ${ }^{106}$

Esta afirmación deja traslucir que, para Ellacuría, la conciliación de la escolástica con el vitalismo es lo menos que se puede hacer para producir una filosofía aceptable, a la altura de los tiempos. Sería una filosofía con una considerable base tomista, orientada a reflexionar, iluminar y diseñar soluciones a los problemas vitales y humanos de las sociedades capitalistas. Sin embargo, Ellacuría no ve este proyecto de síntesis como algo plenamente satisfactorio para lo que realmente busca, y por eso expresa su deseo de que se creen las condiciones para que surja una nueva filosofía que integre lo "que han dejado de aceptable tantos filósofos". Como veremos en el siguiente apartado, Ellacuría abandonará este proyecto de conciliación al caer en la cuenta de las dificultades de su concreción y de las mismas insuficiencias teóricas y prácticas del tomismo y del vitalismo como tales. El encuentro pleno con Zubiri, a principios de los sesenta, será decisivo en este aspecto.

\section{Más allá de la escolástica y del vitalismo}

Es en el ámbito antropológico donde Ellacuría despliega sus esfuerzos intelectuales por tratar de sintetizar la escolástica y el vitalismo, buscando fundamentar filosóficamente una visión unitaria y abierta del ser humano que

104 Ibídem. Ellacuría destaca, especialmente, Geist in Welt de Karl Rahner y Metaphysik de Coreth 105 Ibídem, p. 406.

106 "Posibilidad y modo de aproximación entre la filosofía escolástica y la filosofía vitalista moderna", EF I, p. 249. 
concilie su esencia con su existencia, su naturaleza con su ser histórico, su dimensión de ente natural con su realización vital. Y es que, a su juicio, las dos posturas parcializan un aspecto fundamental de la realidad humana, con lo cual no sólo la falsifican y la encubren, sino que, además, las incapacita para iluminar y contribuir a la resolución del problema existencial humano en las sociedades contemporáneas. La escolástica, al absolutizar la dimensión naturalesencial del ser humano, se cierra a la dimensión histórica del ser humano y se aísla de los problemas vitales cotidianos del individuo concreto; el vitalismo, al absolutizar su dimensión vital, existencial e histórica, y al obviar su radicación esencial y natural, se le escapa el fundamento real de la realidad humana y, por tanto, el sentido transcendente que posee el proyecto humano concreto, de acuerdo a lo que el ser humano es esencialmente.

\subsection{La fundamentación de la apertura del ser humano}

En esta línea Ellacuría busca fundamentar filosóficamente la apertura constitutiva del ser humano hacia la transcendencia, sin recaer en posturas naturalistas o esencialistas ni en posturas puramente vitalistas o existencialistas. Ahora bien, esto pasa por dar respuesta al problema de la unidad de esencia y existencia: ¿cómo conciliar la visión del ser humano como ser personal, dotado de una esencia creada y fundamentada en Dios, con la visión del ser humano como existente libre y creador, capaz de hacer su existencia y modificar su ser a través de actos concretos libres?

Este esfuerzo de fundamentación coincide con el esfuerzo que ha realizado el neotomismo alemán, sobre todo en lo realizado por el método transcendental de Karl Rahner, y que consiste en mostrar que el ser humano en todos sus actos de existencia y de conocimiento está remitido al misterio absoluto de Dios. ${ }^{107}$ Rahner expone esta concepción en su tesis del "existencial sobrenatural", una idea que introduce con el fin de superar una visión extrinsecista de la gracia divina, en relación con la naturaleza humana. ${ }^{108}$ De acuerdo con ella, el ser humano tiene la capacidad fundamental para recibir una posible autocomunicación de Dios debido a que, en cuanto espíritu, está abierto por la gracia al horizonte infinito del ser: "La naturaleza abierta del hombre es, por razón de su transcendencia (potencia obediencial), un posible destinatario

107 Cfr. Martin Maier, "La influencia de Karl Rahner en la teología de Ignacio Ellacuría”, Revista Latinoamericana de Teología (39), 1996, p. 247 ss.

108 Cfr. Martin Maier, "La influencia de Karl Rahner en la teología de Ignacio Ellacuría (II)", Revista Latinoamericana de Teología (44), 1998, pp. 171ss. 
de la autocomunicación libre del mismo Dios en la gracia y en la visión de Dios intuitiva". ${ }^{109}$

Esta posibilidad en el ser humano de recibir una eventual autocomunicación divina, preserva la dimensión de la libertad en el acontecimiento de la revelación. Dios se comunica libremente al ser humano, y éste recibe libremente la gracia divina. En esta perspectiva, contraria a la doctrina neoescolástica, "la gracia no es sino una radicalización de la esencia del hombre y no constituye un piso adicional que se superponga a la naturaleza humana". ${ }^{110} \mathrm{El}$ existencial sobrenatural es así un libre don de la gracia divina, pero, de hecho, es un elemento constitutivo y ontológico de la existencia humana en su realidad concreta, que de esta forma está dado bajo la forma del ofrecimiento de una autocomunicación de Dios.

Por otro lado, hay que destacar la influencia que también pudo tener en el esfuerzo filosófico de Ellacuría la filosofía de Blondel y su postura ante lo sobrenatural, que es uno de los temas capitales de su filosofía. ${ }^{111}$ El hombre está abierto a lo sobrenatural y, por tanto, desde su inmanencia vive de la trascendencia, en ella y por ella. Su primer movimiento ante Dios no es sólo probar su existencia, sino apoderarse de Él. Para probar bastará seguir las reglas de la demostración, pero para apoderarse de Él, es necesario vencer toda forma de naturalismo. La verdadera acción quiere infinitamente el infinito, pero sin poderlo conquistar. No puede uno apoderarse de Dios, sino tan sólo esperar a que Él se dé. Blondel no pretende mostrar que la sobrenaturalización es necesaria y que, por tanto, se nos debe dar, sino que lo natural es completamente insuficiente y que, por ello, es preciso situarse más allá de lo natural y de lo inmanente esperando la llegada del don.

Lo sobrenatural es, en primera instancia, un movimiento inmanente al hombre precisamente bajo la forma de impulsarlo fuera de sí a la espera del don divino, siempre libre por parte de Dios. Querer lo sobrenatural es querer esperar de Dios la divinización, en vez de buscarla por nuestro propio esfuerzo. La dialéctica de la acción muestra que ésta queda inacabada si no sale de sí esperando ser acabada por la gracia. Así el hombre se ve empujado a una opción: el hombre siente una necesidad invencible de apoderarse de Dios, aspira a hacerse dios. $Y$ aquí viene la elección: o ser dios sin Dios y contra Dios, o ser dios por Dios y con

109 K. Rahner, citado por M. Maier, ibídem, p. 171.

110 Martin Maier, "La influencia de Karl Rahner en la teología de Ignacio Ellacuría (II), op.cit., p.172.

111 Cfr. "Introducción al problema del milagro en Blondel”, manuscrito redactado en 1964, EF I, pp.545-558. 
Dios. "Si se escoge la primera parte del dilema, la acción humana fracasa; si se escoge la segunda, es que se ha situado en el plano más allá de lo natural, en el plano sobrenatural, en el recto camino para esperar a Dios, como don gratuito, la sobrenaturalización real". ${ }^{112}$

Sin embargo, es importante destacar en este punto la influencia adicional de Zubiri a través del concepto de religación, utilizado expresamente por Ellacuría en su análisis sobre el ateísmo y la irreligiosidad en las sociedades contemporáneas. ${ }^{113}$ La religación es una dimensión formalmente constitutiva de la existencia. Dios ha fundamentado al hombre de tal modo que su ser pueda separarse de su existencia para poderla ir haciendo libremente; así, ésta se ofrece como existencia liberada que puede tener verdadera transcendencia y vida, ya que le es factible separarse de las cosas para desde sí misma determinar qué hacer con ellas; con lo que, finalmente, goza de actos libres concretos, mediante los que va haciendo concretamente su existencia y, a través de ella, modificando su ser. ${ }^{114}$ Somos, pues, seres constitutivamente religiosos, abiertos a la comunicación con Dios, lo reconozcamos o no al nivel consciente. Todo nuestro ser está abierto y orientado a lo transcendente, que se nos aparece así como una realidad que nos fuerza a asumirnos personalmente $\mathrm{y}$, por consiguiente, a ser más.

\section{2. La vida humana como naturaleza e historia}

Ellacuría está influido por estas concepciones de la apertura constitutiva del hombre a lo religioso, y lo que pretende entonces, dentro de su proyecto de conciliación, es fundamentarla en una antropología que conceptúe adecuadamente la unidad de las dimensiones que están implicadas en esa apertura humana: lo natural y lo sobrenatural, la necesidad y la libertad, la esencia y la existencia, lo inmanente y lo transcendente. El método que Ellacuría utiliza para construir esa antropología consiste en exponer los aspectos centrales de la antropología de Ortega para después criticarlos y complementarlos con los aportes de la escolástica. Veamos cómo procede.

Ellacuría señala que, si bien las dos filosofías apuntan al mismo objeto globalmente considerado, ambas se refieren a niveles distintos de la realidad humana. Ortega se refiere al ser humano como vida, mientras que la escolástica

112 Ibídem, p.556.

113 Cfr. "Ortega, existencia desligada" y "Sobre la irreligiosidad". En estos artículos, Ellacuría sigue muy de cerca el planteamiento contenido en el artículo de Zubiri "En torno al problema de Dios", en Naturaleza, Historia, Dios, 6 ${ }^{a}$ edición, Madrid, Editora Nacional, 1974, pp 361- 39. 114 Cfr. “Ortega, existencia desligada”, EF I, pp 266- 267. 
enfoca al ser humano como ente del que procede esa vida y es determinado por ella. "Ortega no toma como objeto de su cuestión y, por lo tanto, como correlato de esa denominación ser del hombre todo lo que en éste hay, ni siquiera aquel principio ontológico del que pudiera explicarse, porque en algún modo de él procede todo lo que en el hombre hay. Lo cual sería el caso de la filosofía escolástica, que en el nivel de la esencia física apela a la composición de cuerpo y alma, y en el nivel de la esencia metafísica, a la composición de animal racional" 115 .

Conforme con este planteamiento, la escolástica habla del yo como una hipóstasis racional, mientras que el vitalismo habla de proyecto de existencia, de pretensión de ser. La escolástica apunta a "lo que de sustancialidad independiente de todo sujeto y de sustancialidad racional hay en los seres humanos", mientras que Ortega a lo que de "mutación, vitalidad y posible realización de un ser ideal“ hay en ellos ${ }^{116}$. Pero el que ambas filosofías no coincidan en su enfoque sobre la realidad humana, no significa que el nivel afirmado por una implique la negación del otro. La cuestión de la esencia física o metafísica del ser humano, si bien es algo que no le interesa a Ortega, tampoco es algo que éste niegue. Simplemente lo que indica es que "el objeto de su interés y de su cuestión no es el mismo que el de la escolástica. A su vez, la escolástica, cuando recalca como ser del hombre sus principios físicos [...] no niega que se dé, claro está, esa vida realmente nueva y específica del hombre, aunque el objeto de su interés sea más bien el ser del hombre aún existente, que su existencia en el sentido de vida humana"117.

Aparentemente, según Ellacuría, Ortega niega la existencia de una sustancialidad permanente, pero más bien su oposición va contra una sustancialidad fija, de tipo parmenídeo. Y, aparentemente, también esta es la posición de la escolástica, cuando combate las tesis de la filosofía vitalista. "Pero el negar cualquiera de las dos realidades sería falso, ya que manifiestamente se requieren, la una en virtud de una demostración basada últimamente en el principio de razón suficiente, y la otra en virtud de una experiencia inmediata que no puede ser negada". ${ }^{118}$

Desde esta perspectiva, Ellacuría cree que es posible la conciliación de ambas antropologías en muchos aspectos, aunque no lo sea en todos. Por ejemplo, la

115 "Técnica y vida humana en Ortega y Gasset", EF I, p. 458.

116 "Posibilidad y modo de aproximación entre la filosofía escolástica y la filosofía vitalista moderna", EF I, p. 244.

117 “Técnica y vida humana en Ortega y Gasset”, EF I, p. 459.

118 "Posibilidad y modo de aproximación entre la filosofía escolástica y la filosofía vitalista moderna", EF I, p. 245. 
doctrina escolástica sobre lo racional "puede ser completada, y precisamente, con muchas de las observaciones de Ortega". El que unos hablen de la naturaleza y del estado real-potencial del ser humano, y el otro de historia vital, en un proceso de actualización del yo ideal, "ilumina el sentido de complementariedad que se puede dar entre la concepción intelectualista de la escolástica y la vitalista de Ortega”. Además, "la corrección que supone el aristotelismo de la doctrina parmenídea es ya un avance, como lo es el tomismo respecto del racionalismo extremo". ${ }^{119}$

Delimitados los dos niveles de realidad elegidos por las dos filosofías, la primera cuestión a resolver es lo de la radicalidad de esos niveles para dar con el ser del hombre y determinar cuál de los planos -el del ser humano como vida y del ser humano como ente que origina esa vida- cubre mejor la realidad integral del ser humano. La respuesta pasa por entender adecuadamente el planteamiento de Ortega sobre la vida humana y la especificidad que la caracteriza. A continuación analizaremos los aspectos centrales que Ellacuría destaca de dicho planteamiento.

\section{2. 1. La vida humana como proyecto}

La vida humana, a diferencia del animal, tiene que ser inventada. "Al hombre después de cumplir con su puro sostenerse en la naturaleza, con su vida animal, le sobra todavía vida [...] su vida no se entiende sin hacer, vida humana sin hacer humano [...] Inicialmente, el hombre arranca en cero existir humano, pues lo que de humano hay en su existencia no le es dado, como la vida natural del animal, sino que tiene que hacérselo". ${ }^{120}$ En este sentido, la vida humana se presenta en forma de hueco, algo que debe estar lleno y no lo está todavía, que debe llenarse "porque no es un ámbito contradictorio respecto de las posibilidades humanas, sino de una positiva posibilidad que es, además, urgencia existencial". ${ }^{121}$

Frente a esta afirmación, Ellacuría apunta que la invención de la propia vida implica, en el ser humano, la existencia previa de "un algo que no es animal" y que fundamenta la urgencia que se presenta en él de trascender el ámbito puramente animal. En otras palabras, el hecho de que el ser humano ejecute actos que no son biológicos, que él mismo va inventando, supone necesariamente la existencia de un yo, que es la instancia "que tiene que atender las urgencias biológicas, pero también el que puede apartarse de ellas

119 Ibídem, p. 246.

120 “Técnica y vida humana en Ortega y Gasset”, EF I, p.450.

121 lbídem, p. 451. 
para vacar a quehaceres no biológicos”. ${ }^{122}$ El ser humano aparece así dotado de elementos vitales y de condiciones esenciales de posibilidad para inventar su propia vida, dotado, por tanto, de potencias y facultades específicas que le posibilitan realizar actos estrictamente humanos. No es que estas potencias sean ya el ser del hombre, ni vida formalmente humana, ya que ésta no es tal por proceder de facultades específicas del ente que es el hombre, sino por su propio carácter de no dada, de no impuesta; de actualización de un proyecto. Una de estas facultades es la imaginación, que no es una facultad sensitiva ya que de ella proviene lo que va a ser totalmente distinto y superior a la vida animal, la vida humana. Por esta facultad "la vida humana no tiene el carácter de un repertorio fijo de actos dado e impuesto" y la que hace, por tanto, que ésta no aparezca como una mera realidad natural inmersa en un dinamismo con una trayectoria irremediable desde dentro de sí misma. Por ella, pues, la vida humana trasciende de la realidad natural. El ser humano tiene así una naturaleza que es superada y de la que se libera la vida humana. Esto es evidente "desde el momento en que se apela a una imaginación que nos es dada y con la que nos encontramos, de la que proviene la invención de lo que será la vida humana". ${ }^{123}$

El punto central que Ellacuría quiere resaltar aquí, contra Ortega, es que la vida humana, con toda su especificidad que le es propia, no es inteligible si no se la hace radicar en la propia esencia y estructura del ser humano, en su realidad física y que, por tanto, la posibilidad misma del proyecto y de tal proyecto está condicionada por el ente que es el hombre:

En ese sujeto psíquico es donde se sitúa la vida humana, allí radica la condición de posibilidad de retirarse de las exigencias biológicas, allí es donde cada quien puede ensimismarse, allí principalmente se fundamenta lo que de genérico tiene la pretensión que es el hombre en cuanto especie. ${ }^{124}$

\subsection{La vida humana como choque dialéctico entre hombre y mundo}

El ser humano "es ese ente extraño [...] a quien se pone la condición necesaria, si quiere seguir existiendo, de estar y de hacer su vida con otro ente que llamamos mundo o naturaleza”. ${ }^{125}$ ¿En qué relación se encuentra este mundo con el hombre? Ante todo como algo distinto, pero a su vez como algo 
necesario y como condición de posibilidad de arranque de la vida humana. "Donde la filosofía aristotélica señala que sin sensibilidad no le es posible al hombre el ejercicio de su vida intelectual, Ortega va más allá por los dos extremos, diciendo que sin mundo no es posible la vida humana que es de por sí actualización y ejercicio". ${ }^{126}$ El ser humano necesita, pues, del mundo como base de su existencia, pero también como incentivo de vida y como material de construcción.

Desde aquí se puede deducir a priori que lo que el mundo ofrece al ser humano no puede ser un cúmulo de facilidades sin dificultad alguna, porque entonces sus seres serían coincidentes, lo que contradiría la experiencia vital. Esto se puede comprobar por la presencia de necesidades como expresión de la “menesterosidad del hombre", precisamente por su relación con el mundo. Se iluminan así las estructuras ontológicas del ser humano y del mundo, lo que a su vez permite prever cuáles pueden ser las relaciones entre ambos entes y el modo de concretizarse su ser diverso. "El hombre siente el mundo como algo distinto de él porque a cada momento le ofrece resistencia [...]. No se trata, sin embargo, de cualquier resistencia; también las piedras y las plantas encuentran resistencias, $y$, con todo, son presentadas por Ortega como ejemplos de coincidencia con su mundo de ausencia de necesidades". ${ }^{127} \mathrm{El}$ ser humano siente sus necesidades como imposiciones que vienen de fuera a su ser auténtico. Y esto nos hace ver, según Ellacuría, que las necesidades humanas son cualitativamente distintas a las necesidades animales, por lo que el ente humano tiene una relación con el mundo muy distinta que la que tiene el animal, que da origen a un tipo de vida cualitativamente distinta.

El mundo tampoco puede ser para el ser humano un ofrecimiento de puras dificultades, o dicho de otra manera más radical, "el ser del mundo y el ser del hombre no pueden ser totalmente antagónicos", de lo contrario, la vida humana no sería posible:

Si vida humana es lo que hace un ente que necesariamente, para hacerla, debe estar en otro ente y debe hacerla con este otro, el ente que llamamos mundo no puede ser lo totalmente antagónico, porque entonces el ente que es el hombre carecería de aquello sin lo que no puede vivir, ya que él en esta línea de la vida humana es una mera posibilidad. Por otra parte, 
dos entes que por naturaleza están tan estrechamente ligados, necesariamente deben contar con cierta comunidad de ser. ${ }^{128}$

La conclusión es que "el mundo es, en cierto sentido un conjunto de cosas, pero su ser formal con relación al hombre es ser un conjunto de facilidades y dificultades; las facilidades que nos ofrece hacen posible la vida, las dificultades con que nos estorba nos demuestran su ser distinto y nos incitan, consecuentemente, a una vida distinta". ${ }^{129}$ El mundo se le presenta al hombre como algo con lo que puede realizar el proyecto que es y como algo que va a servir como una especie de máquina instrumental para producir su propia vida. "En su materia lleva el mundo una posibilidad de máquina, y el hombre va a empeñarse en aprovechar el ser de máquina propio del mundo para encontrar más facilidades que dificultades, aunque nunca el mundo podrá realizar sin más el ser del hombre". ${ }^{130}$ Pero es el mundo el que ofrece al ser humano la posibilidad de existir y a éste le es absolutamente imposible realizar su proyecto vital sino es en una y con una naturaleza. "La naturaleza podrá y tendrá que ser transformada, pero nunca dejará de ser naturaleza y nunca dejará de ser indispensable para la existencia humana". ${ }^{131}$

\section{2. 3. La vida humana como problema}

El hecho es que el ser humano "no es de antemano una esencia determinada a la que no le quede más que actualizarse, sino que es un proyecto de difícil realización; no tiene que efectuar un contenido ya determinado, sino, ante todo, tiene que darse un contenido, realizar el programa que, por lo pronto, representa aquello en que consiste" ${ }^{132}$.

Esto, efectivamente, resulta ser un problema, y "como la vida es formalmente la invención y la realización de un proyecto en una circunstancia determinada, resulta que es, a un tiempo, problema y quehacer". ${ }^{133}$ La realidad humana aparece así en Ortega con un esencial carácter práxico: “Al hombre le sucede que para ser tiene que actuar, que no es sino esa actuación; es lo que se haga de sí mismo, lo que se autofabrique". ${ }^{134}$

Frente a la escolástica, que ve la realización humana como mera actualización

\footnotetext{
128 Ibídem.

129 Ibídem, pp. 455-456.

130 Ibídem, p. 477.

131 Ibídem.

132 Ibídem, p. 479.

133 Ibídem.

134 Ibídem.
} 
de lo que el ser humano ya es por naturaleza, Ellacuría resalta lo incierto y problemático de esa realización debido a que es algo que no está asegurado por la mera actuación de potencias naturales. La realización plena del ser humano descansa en lo que él pueda hacer, según las posibilidades que le ofrece su circunstancia:

Radicalmente, el vivir humano apunta a realizar precisamente ese yo que somos sin todavía realizarlo, con los elementos reales que ya tiene un ser efectivo, pero que todavía no ha cobrado categoría de ser humano. Mientras yo no hago algo, no me encuentro a mí mismo, y en vista de que tengo que hacer algo, necesito de diferentes elementos reales para ello. Mas ciertamente aquello que ya hay, aquello que se me da para que con ello haga mi vida, no realiza por sí y sin más el ser del hombre. ${ }^{135}$

El que el ser humano posea ya una esencia determinada, con unas potencias y facultades específicas, no le garantiza que realice su ser pleno y auténtico. Afirmar lo contrario supone una visión abstracta del ser humano, que soslaya su radical instalación en unas circunstancias determinadas y que considera que sólo sus principios físicos garantizan automáticamente la realización de su humanidad. El que el hombre sea un compuesto de alma y cuerpo, que lo determina metafísicamente como animal racional, es algo que le capacita para realizar, como un yo personal, actos libres y humanos e inventar, por consiguiente, su vida a través de un programa o proyecto, pero ello no define completamente su ser; la realización plena de su ser se juega en lo que pueda o no hacer en su vida concreta, de acuerdo al proyecto o ideal que se ha trazado:

En su última expresión formal, pues, la vida humana consiste en realizar el ser extranatural del hombre. Así se entiende por qué la vida para ser tiene que actuar, y no es sino en esa actuación, a diferencia de las cosas que tienen ya de por sí su ser fijo o plenamente actualizado o ya determinado para su futura actualización. ${ }^{136}$

Sin embargo, Ellacuría vuelve a enfatizar, contra Ortega, que la realización del proyecto de ser supone un sujeto real, un yo con una estructura ontológica determinada, que es 
el centro al que todo se atribuye y del que todo, en última instancia procede, pues regulándose a sí mismo todo lo regula; el centro que, por de pronto, es el motor que se afana y el ideal o proyecto conforme al cual todo el resto de lo humano se mueve [...] Gracias a ese yo, no es la vida un azar derrochador de energías, sino una actuación conforme a un plan. Vale decir que, gracias a él, la vida encuentra tareas efectivamente humanas bajo la gran tarea radical de hacer efectivamente un hombre con lo que no es sino posibilidad imaginaria, encuentra una fuerza y un plan para realizar esa tarea, y se sirve de lo que no es yo para constituir el yo como ente. ${ }^{137}$

Ortega resalta el carácter problemático y proyectivo de la existencia humana, pero no explica adecuadamente el fundamento real que la posibilita, la regula y la orienta, y que se identifica con el ente que actúa y que asume la tarea de realizarse como ser humano, tratando de realizar su ser extranatural con el material de la naturaleza en la que está inserto. Ortega describe bien la peculiaridad de la vida humana, porque esa vida es radicalmente la forzosidad de hacer su vida en el mundo, con todas las dificultades y facilidades que le ofrece. Pero lo que olvida es que "será forzoso sólo en la medida en que el yo quiera seguir viviendo, y quiera seguir viviendo como hombre, es decir, quiera ser algo más de lo que le es impuesto desde fuera y quiera serlo en busca de lo que él personalmente tiene que ser"138.

En este sentido, para Ellacuría lo importante en la definición de la vida humana es la capacidad y disposición del ente humano para ensimismarse y actuar en función de lo que quiere ser o lo que ha proyectado ser, lo cual está determinado por el tipo de ente que es, con su propia estructura y con todas las potencias y facultades específicas que lo diferencian del mero ente animal o vegetal. Por tanto, no está de acuerdo con Ortega quien considera que "el hombre, en cuanto cuerpo y alma, es, respecto del yo programático, naturaleza, circunstancia o mundo", obviando que

el hombre no puede realizarse por sí mismo, más aún, necesita un alguien que lo realiza, además de un algo con que realizarlo; y ese alguien, que no es todavía el yo auténtico, es el yo psíquico con sus posibilidades, con sus energías peculiares que le permitirán no sólo atender a sus necesidades biológicas, 
sino también a su verdadera vida. Verdadera vida [...] porque es la que plenamente corresponde a sus mejores posibilidades entitativas, a la esencia, a la estructura y al dinamismo que le es propio, a su esfuerzo que no queda cumplido si se pierde sólo en actividades biológicas o en actividades humanas devaluadas, al deseo real de lo que aún es irreal, a su personal y efectiva capacidad de imaginarse y de quererse. Como ser todavía no es, pero como ente está dotado con lo requerido para ser. ${ }^{139}$

\section{2. 4. La vida humana como la realidad radical}

La cuestión que Ellacuría pretende resolver ahora es "cuál de los dos planos antes diferenciados, el del hombre como vida y el de hombre como ente del que procede esa vida y es determinado por ella, cubre mejor ese fenómeno integral que llamamos hombre"140. 0 formulado de otra manera:

[...] el ser del hombre tiene la extrañísima condición, tantas veces apuntada, de ser afín al ser de la naturaleza, pero sin llegar a coincidir con el de ella; de tener media porción inmersa en la naturaleza, pero con otra media que trasciende de ella. Como ser metafísico tiene afinidad y diferencia con el ser de la naturaleza, como ente que hay tiene como parte suya un ente que es natural. Lo que nos enfrenta con la pregunta capital: ¿a qué de todo esto llamaremos el ser sin más del hombre? ${ }^{141}$

Para darle respuesta, Ellacuría reinterpreta la famosa frase orteguiana "yo soy yo y mi circunstancia”, tratando de conciliarla con la visión escolástica. El primer yo de la frase, según Ellacuría, hace referencia al yo total, a la totalidad de la persona, "uno de cuyos ingredientes es el yo entendido como sujeto del vivir, como el centro de una circunstancia, que es el otro ingrediente de aquella totalidad". ${ }^{142}$ Ellacuría señala que este último yo es ya de por sí alguien capaz de ser sí mismo, con la capacidad de hacer suya a su circunstancia, aunque no es en pleno sentido persona, por cuanto es una abstracción, un yo considerado como contradistinto de la circunstancia. Por el contrario, el yo primero es la persona total, en cuanto es un yo en sí mismo circunstancial, algo plenamente concreto. Ortega se refiere al yo total que es lo que cada uno es con su ser concreto, vinculado intrínsecamente con su circunstancia. En este sentido, 
Ortega se pregunta por algo más amplio que aquello por lo que se pregunta la escolástica, que sólo centra su atención sobre la determinación del yo separado de la circunstancia:

Ortega habla del yo vivo, del yo que cada uno de nosotros viviente es, que, en cuanto denominación, evita todo momento de abstracción para atender a la realidad tal como se da; por lo tanto no atiende in recto al yo sujeto y a su estructura ontológica, aunque no niega que la tenga. ${ }^{143}$

Se puede, decir, en este sentido, que en la realidad lo que se da es el yo total, es decir, el yo inmerso en unas circunstancias determinadas que "integra bajo la forma de vida ingredientes o constitutivos muy diversos hechos uno". ${ }^{144}$ El problema con Ortega es que apunta a esta totalidad, pero sólo resalta sus aspectos vitales sin atender los aspectos ontológicos de sus dos momentos constitutivos, en especial los del yo sujeto, que está mucho más atendido por la escolástica. Bajo este punto de vista, “los criterios orteguianos son justos, pero no acabados explícitamente. Son acomodados para valorar en ese yo total su elemento cimero de vida, de existencia humana, que, una vez alcanzada, permite preguntar por sus condiciones de posibilidad, tanto en el orden físico como metafísico; pero no dan apoyatura explícita para desde ellos dar con el ser total del hombre". ${ }^{145}$

La consecuencia de este análisis es que ni el yo orteguiano ni el yo escolástico, considerados por separado, nos dan el nivel donde se encuentra el ser del hombre. El nivel donde se encuentra el ser del hombre es en el yo total que integra a los dos bajo forma de vida. En esta totalidad, la escolástica le da preeminencia a la raíz sobre los frutos, Ortega al fruto que está en la cima. En efecto, Ortega resalta la dimensión de la vida bajo la forma de programa o proyecto de ser; la escolástica, "aquel último fondo, efectivo y total, al que se refiere todo lo que el sujeto hace y del que procede últimamente todo lo que hace". ${ }^{146}$ Los dos puntos de vista son unilaterales porque la vida ni es sólo esencia o naturaleza ni sólo proyecto o historia. La vida humana es, a la vez, esencia y existencia, naturaleza e historia; es la unidad dinámica y efectiva de un yo en un mundo y de un mundo en un yo, y sólo desde esta perspectiva total se la puede considerar como la realidad radical. 
Desde esta última consideración, la vida "se presenta como una interrelación íntima de un yo con lo no yo, una interrelación que admite las formas más diversas; una interdependencia, por otra parte, tan fundamental y estrecha que, tal como aparecen en mi vida, cada uno de los extremos no es lo que es sino desde el otro y con el otro". ${ }^{147}$ En este esquema, el yo en cuestión no agota todo lo que es la vida de cada cual, porque a ella pertenece también la otra mitad que es el mundo; por otra parte, dentro de la unidad total que es mi vida se presenta "como posibilidad de subjetivación y ensimismación todo lo que tiene que ver conmigo". ${ }^{148}$ Así la vida no es "el resultado de lo que el yo hace con el mundo, esto es, como un conjunto de actos que ni son el yo ni son el mundo, sino que es la realidad total, comprehensora del yo y del mundo en su mutuo intervenirse". ${ }^{149}$

Se puede afirmar, por tanto, que la vida humana es la realidad radical, siempre y cuando se la entienda desde este nivel total. En otras palabras, la vida humana es el ser del hombre si por ser del hombre "se entiende aquello que comprehende bajo sí todo lo que en el hombre hay bajo la forma y unidad en que es". El mismo Ortega da pie para esta afirmación al sostener que "el punto de arranque de la filosofía no es ya un principio abstracto, sino mi ser individualísimo, es decir, lo que en concreto es cada uno" y al hacer "parte de la vida de cada uno al yo que hace en la vida, al hacerse y a lo hecho en la vida". ${ }^{150}$ El problema es que en sus textos la vida aparece "como si no fuera más que la unión de los actos sucesivos en que va desenvolviéndose mi vida", sin hacer intervenir al "yo que los vive y la unidad nuevamente vista del yo en el mundo, lograda precisamente en el hacerse de la vida". ${ }^{151}$

Así, en la óptica ellacuriana el ser humano aparece sumergido en la realidad de su mundo, optando y actuando con el fin de construir su vida de acuerdo a las posibilidades efectivas que le ofrecen las circunstancias, esforzándose por realizar su yo ideal, su personalidad, que representa su auténtico ser. Expresado esto mismo en términos de conciliación de las dos posturas, se podría formular así:

Nuestro yo-hipóstasis, frente al mundo que lo oprime y con el cual necesariamente tiene que habérselas, construye su vida que debe alcanzar la medida del yo-ideal, que es su autentico yo, el que debe ser. Por eso hay drama, porque tenemos que

147 Ibídem, p. 485.

148 Ibídem.

149 Ibídem.

150 Ibídem, p. 489. Cfr. J. Ortega y Gasset, ¿Qué es filosofía?, Madrid, 1957, pp. 250-251.

151 lbídem. 
ir haciendo nuestra vida y nuestro yo, trayéndolo desde su idealidad posible a su actualización en nuestro tiempo; por eso hay tragedia, porque muchas veces no llegamos a coincidir con ese nosotros-mismos que somos, pero que estamos llamados esencialmente a ser. ${ }^{152}$

En este sentido, vida es la actualización dinámica de un yo en un mundo, la realización de posibilidades de un sujeto en el mundo que lo circunda y con el que va ejecutando el proyecto de su vida. Y esto significa que si bien la personalidad virtual del yo-sujeto se actualiza y formaliza en la vida y por la vida, la vida, a su vez, surge como actualización de ese yo-sujeto, actualización que es posible por la incitación y el condicionamiento de unas circunstancias.

Y en esta actualización, lo que de ente hay en el yo-sujeto es algo con lo que éste cuenta como posibilidad para ir realizando el proyecto en forma concreta y total. Si en este aspecto, eso que de ente hay en el yo-sujeto en cuanto es algo ya dado- tiene el carácter de mundo, en otro aspecto se contradistingue de lo que es puramente mundo, "porque la posibilidad ofrecida por él al proyecto se presenta con una tesitura totalmente diversa a la que es propia de la circunstancia en su carácter puro de tal". ${ }^{153}$ Por esta razón, la jerarquía del yo-sujeto y de la circunstancia, según Ellacuría, es muy distinta en la estructura total de la vida humana. Y esto significa que sólo un ente que metafísicamente se define como persona tiene la potencialidad para desplegar una vida nueva y distinta en unidad con unas circunstancias que le condicionan y limitan, pero que, a la vez, le posibilitan la realización de su ser verdadero, de su personalidad. ${ }^{154}$

\section{3. Las aporías del proyecto de conciliación}

Como podemos apreciar en todo este análisis de la antropología orteguiana, Ellacuría asume la visión aristotélica-tomista de la esencia humana como una concepción adecuada para explicar la estructura del ente humano y su especificidad como persona y no ve mayores problemas para conciliarla con la visión antropológica de Ortega, siempre y cuando se la entienda

152 "Posibilidad y modo de aproximación entre la filosofía escolástica y la filosofía vitalista moderna", EF I, p. 245.

153 Ibídem, p. 495.

154 Cfr. ibídem, pp. 494. Ellacuría cita aquí a K. Rahner: "Con el término 'persona' nos referimos al hombre, en cuanto que puede disponer y dispone de sí mismo (como naturaleza) en libertad. Con el término 'naturaleza' nos referimos a aquello que antecede a este actuar libre del hombre como su condición de posibilidad, y que entraña una norma que limita la soberanía autónoma de la libertad”. K.Rahner, Schriften zur Theologie, vol. 2, 3 Aufl., 1958, Benzinger, p. 86. 
adecuadamente. En este sentido, Ellacuría aclara que "no se haría justicia a esta concepción si se estimase la unión del cuerpo y el alma como una juntura cualquiera de dos fardos atados el uno al otro; al contrario, se trata de una unión sustancial de dos principios incompletos, que no se completan sino en una unidad superior, intrínseca y esencial"155. Entendida así la unidad de los dos principios que conforman la realidad física del ser humano, se hace posible pensar la naturaleza humana como una naturaleza nueva y como principio de unas acciones y de una vida nueva, compatible, por tanto, con la concepción orteguiana de la vida humana.

Frente a la afirmación de Ortega de que el ser humano no es su cuerpo ni su alma, Ellacuría alega que "tampoco ningún escolástico diría nunca que yo soy mi cuerpo o yo soy mi alma, porque en su sentido concreto yo soy algo más que mi cuerpo y mi alma, y en su sentido abstracto de personalidad, aquello por lo que la persona es persona, por la misma razón formulada más abstractamente" ${ }^{156}$. "Ortega -señala Ellacuría- no ha entendido bien nuestra definición del hombre como animal racional, precisamente por desatender lo que en cada individuo y en la especie hay de naturaleza fija; por eso, sin mucha seriedad científica, pretende sustituir la antigua con una nueva definición, ya que le parece inválida aquélla por equipararla con la res cogitans cartesiana"157. Por ello, si se la entiende adecuadamente, es perfectamente compatible con sus análisis de la vida humana y que concretizan "el unívoco e indiferenciado animal racional como potencialidad de muy distintas actualizaciones posibles" ${ }^{158}$.

Congruente con esta postura, Ellacuría afirma que el proyecto representa la plena realización de las mejores potencialidades y posibilidades de nuestra naturaleza racional; es decir, el proyecto representa el yo actualizado y perfecto -el yo ideal- que sería la "vocación con la que Dios llama a cada uno de nosotros para que realicemos ese proyecto que aún no somos -pero que debemos intentar ser". ${ }^{159}$

Aquí se vislumbra un problema teórico que influirá decisivamente en el abandono posterior de este intento de Ellacuría por conciliar las posturas escolásticas con las vitalistas. El problema radica en que busca fundamentar una antropología de tipo historicista a partir de una antropología de tipo naturalista. ¿Cómo

155 Ibídem, p. 459.

156 Ibídem, p.470.

157 "Posibilidad y modo de aproximación entre la filosofía escolástica y la filosofía vitalista moderna", EF I, p.239.

158 Ibídem, p. 240.

159 Ibídem, p. 239. 
fundamentar el carácter vital e histórico del ser humano a partir de una presunta esencia o naturaleza de carácter inmutable, que está determinándolo por debajo de sus manifestaciones y actuaciones?

El problema básico es que la visión escolástica de la esencia humana no es adecuada para fundamentar el carácter histórico del ser humano. En su análisis, Ellacuría, siguiendo a Ortega, afirma que en el ente humano, a diferencia de los otros entes, su potencialidad no coincide con su realización; que su ser no es algo ya dado, sino un proyecto, algo que el ser humano tiene que ir inventando y haciendo en su vida biográfica. Sin embargo, por muy específica que sea la esencia humana respecto de los otros entes, es una esencia cerrada en el sentido de que ella contiene potencialmente todo lo que un ser humano puede dar de sí en su despliegue vital. Por muy diversas y variables que sean las concreciones que puede alcanzar el animal racional en su vida, a través de sus actos libres y opcionales, ninguna de ellas representa una verdadera novedad respecto a lo que ya es en sí el ente humano por naturaleza. La esencia fija de antemano los límites de la variabilidad de las concreciones vitales y lo que el ser humano pueda actualizar en ellas -que nunca será algo más de lo que ya está contenido potencialmente en la naturaleza humana-.

Aun entendida en toda su unidad y concreción, la vida humana se convierte así en una mera actualización y revelación de lo mismo, de lo que ya es en sí; deja de ser la "realidad radical" en la que se inventa y se crea el "ser del hombre histórico", para convertirse en un mero espacio de desvelación de una esencia inmutable; algo así como una especie de “colchón” en el que se despliega una misma esencia aunque con diversos ropajes y vestidos.

El punto central de esta crítica es que el esquema aristotélico de acto-potencia o su equivalente materia-forma, son esquemas que han sido forjados para explicar la estructura y el cambio de realidades naturales, pero no para explicar realidades que se constituyen históricamente, como es el caso de la realidad humana. Ellacuría intenta fundamentar el carácter histórico de la existencia humana a partir de una esencia que, por definición, es cerrada y ahistórica; que, aunque posea una "porción extranatural", ella ya contiene en sí, virtualmente, todo lo que el ser humano puede ser y hacer con su vida.

En está línea el mismo Ortega ya había señalado que el idealismo no ha sido capaz de superar las concepciones naturalistas del ser humano, por aplicar, al espíritu, la doctrina antigua sobre el ser, y que se refleja en la utilización del concepto de res, que está vinculado, en la ontología tradicional, a natura, la cual es entendida desde Aristóteles como physis, esto es, el principio o arjé 
invariable de los cambios y las variaciones de las cosas: "La res es concebida como algo que tiene su entraña -en su arjé- la misma condición ontológica que el concepto y el triángulo: la identidad, la invariabilidad radical, la estabilidad, la profunda quietud que para el griego significa el vocablo ser"160. Por esta razón, Ortega se resiste a definir el ser humano como naturaleza o como espíritu y trata de pensar la vida humana, tal y como se presenta en su primaria desnudez, mediante conceptos novedosos fuera del marco de la ontología tradicional.

El intento de Ellacuría por conciliar la escolástica con el vitalismo se justifica por cuanto pretende fundamentar el modo humano de ser mostrado en los análisis fenomenológicos de Ortega desde la propia estructura y esencia del ente humano. En su opinión, Ortega no ha llegado siquiera a los planos penúltimos en su explicación de la vida humana como realidad radical debido a que ha confundido el plano fenomenológico con el plano ontológico o metafísico, y ha absolutizado, por tanto, las determinaciones vitales del ser total del ser humano. Pero si el intento se justifica, el modo de realizarlo deja mucho que desear por los problemas que hemos apuntado antes.

Debido a las aporías que implica semejante síntesis, Ellacuría abandonará en poco tiempo esta postura, aunque permanecerá con la inquietud de encontrar una filosofía nueva que explique unitariamente la totalidad de la realidad humana y su apertura a la transcendencia.

\section{Zubiri como modelo de un filosofar vital y auténtico}

Estos aspectos y orientaciones son los que determinan los intereses filosóficos de Ellacuría en esta etapa, y desde ellos se comprenden mejor los motivos que lo llevaron a tratar de fundamentarlos y desarrollarlos desde la filosofía de Zubiri. Antes de conocer personalmente a Zubiri, en septiembre de 1961, Ellacuría ya tenía conocimiento de su filosofía través de Naturaleza, Historia y Dios, obra que cita en sus primeros escritos filosóficos ${ }^{161}$. A partir de las referencias que hace de Zubiri en estos escritos, se puede deducir que éste no sólo le proporcionó un modelo de filosofía y de filosofar, congruente con el proyecto de síntesis integradora que estaba intentando realizar, sino también le dotó de conceptos y enfoques novedosos para pensar la problemática existencial del ser humano.

160 J. Ortega y Gasset. La Historia como Sistema, Revista de Occidente, Madrid, 1970, VI, p. 30. 161 Cfr. "El despertar de la filosofía", "Ortega, existencia desligada", "Sobre la irreligiosidad" y "Filosofía en Centroamérica", op.cit. 
Esto nos estaría indicando que la decisión de Ellacuría de realizar posteriormente su tesis doctoral sobre Zubiri, no fue algo casual, sino algo que ya se venía incubando en su mente desde mediados de la década de los cincuenta y que se decantó después, en el transcurso de sus estudios teológicos, en Innsbruck, cuando las aporías inherentes al esfuerzo de síntesis de la escolástica y el vitalismo se le hicieron evidentes.

En este momento, Ellacuría ve en la obra de Zubiri "una muestra espléndida de un filosofar vital, auténtico"162, y la interpreta como "un modelo de juntura entre lo clásico y lo moderno, entre lo esencial y lo existencial"163. Concretamente, son tres los temas de Naturaleza, Historia, Dios que le causan mayor impresión: La idea sobre el filosofar, la historicidad del ser humano como acontecer y el concepto de religación, al que aludimos anteriormente.

Con relación a la idea de filosofar, lo que Ellacuría aprecia de Zubiri es su visión de la filosofía como resultado de una vida filosófica, de un filosofar personal, y que es un planteamiento parecido al que había apreciado en el modelo de vida intelectual de Ángel Martínez. La filosofía no es una ciencia que se aprende, ni un conjunto sistematizado de tesis; tampoco se identifica con el estudio culturalista de la historia de la filosofía, ni mucho menos con un sistema filosófico determinado. La filosofía se identifica con la actitud radical del filosofar mismo ${ }^{164}$ :

Lo que Kant decía, que no se puede aprender filosofía sino que únicamente puede aprenderse a filosofar, y que Zubiri complementa diciendo que sólo se aprende filosofía poniéndose a filosofar, es algo que no puede pasarse por alto. No se llega a la filosofía sin filosofar y, consecuentemente, no se transmite filosofía sin filosofar por parte del transmisor y por parte del receptor. Pero el filosofar no es sólo un proceso intelectual, un

\footnotetext{
162 "Filosofía en Centroamérica”, EF I, p. 403.

163 Primera entrevista de Ellacuría con Zubiri, San Sebastián, 8 de septiembre de 1961. Archivo Ignacio Ellacuría, UCA, San Salvador.

164 Zubiri lo explica así: “Lo difícil del caso es que la filosofía no es algo hecho, que esté ahí y de que baste echar mano para servirse a discreción. En todo hombre, la filosofía es cosa que ha de fabricarse por un esfuerzo personal. No se trata de que cada cual haya de comenzar en cero o inventar un sistema propio. Todo lo contrario. Precisamente, por tratarse de un saber radical y último, la filosofía se halla montada, más que otro saber alguno, sobre una tradición. De lo que se trata es de que, aun admitiendo filosofías ya hechas, esta adscripción sea resultado de un esfuerzo personal, de una auténtica vida intelectual. Lo demás es brillante "aprendizaje" de libros o espléndida confección de lecciones "magistrales". Se pueden, en efecto, escribir toneladas de papel y consumir una larga vida en una cátedra de filosofía, y no haber rozado, ni tan siquiera de lejos, el más leve vestigio de vida filosófica. Recíprocamente, se puede carecer en absoluto de "originalidad", y poseer, en lo más recóndito de sí mismo el interno y callado movimiento del filosofar”. X. Zubiri, “Nuestra situación intelectual”, Naturaleza, Historia, Dios, op.cit, pp 27-28.
} 
encadenamiento riguroso de razones específicas, sino, antes que todo, una forma de vida; y esto no en el sentido puramente óntico, conforme al cual en todo ejercicio de la inteligencia hay una realización vital, sino en un sentido mucho más radical y total, en cuanto, sin dejar de ser lo que es como función teórica, es presencia de la realidad subjetivada que cobra conciencia -luz- de sí, en una autoposesión plena. ${ }^{165}$

En otro artículo, Ellacuría plantea la misma idea en el contexto de su crítica a la escolástica:

Si la filosofía ha adquirido ciertas verdades sobre la realidad, pudiera parecer que bastaría con conocerlas y entenderlas para ser filósofo, es decir, para estar efectivamente dentro de ella. Y si embargo, no es así. Conviene recalcar esto con toda violencia delante de la gente que va a estudiar filosofía, predominantemente dentro de la escolástica, entendida como un conjunto sistematizado de tesis que están ahí como soluciones anteriormente a estar como ignorancias y problemas [...] La filosofía no es algo hecho de una vez o de muchas veces por todas las restantes. 0 , si se prefiere, lo hecho en filosofía no puede "conocerse" sino en su hacerse, en su esforzado hacerse. ${ }^{166}$

La historicidad del ser humano es otro concepto que Ellacuría asimila de Zubiri, y que tiene similitudes con el planteamiento de Ortega sobre la vida humana como proyecto. Es en su artículo sobre los presocráticos donde más explícitamente aparece su utilización y aplicación. ${ }^{167} \mathrm{El}$ tema está planteado con relación a la historicidad y situacionalidad intrínsecas del filosofar y de la filosofía: una filosofía no nace del vacío; necesita de un determinado tipo de individuo, de un determinado contexto y de una precisa evolución histórica:

[...] es imposible la intelección de un sistema filosófico, en toda su proyección de respuesta mental a un problema enfrentado con autenticidad y aun con trágico dramatismo, sin internarse en la historicidad, al menos condicionante, de la vida del filósofo en cuanto tal y de su filosofía como resultado de una vida

165 "Filosofía en Centroamérica", EF I, p. 402.

166 "Introducción a la filosofía”, EF I, p.598.

167 Los artículos de Zubiri que Ellacuría cita, son: "El acontecer humano. Grecia y la pervivencia del pasado filosófico" y "Sócrates y la sabiduría griega", en Naturaleza, Historia, Dios, op.cit. 
filosófica, de un filosofar personal. Es indudable la necesaria disparidad que habrá entre un presocrático, sirva de ejemplo, y un positivista del siglo pasado: las circunstancias históricas, con diferenciadísimos horizontes espirituales y aun materiales, prestan un cúmulo de problemas, unos utensilios para el trabajo mental, unos principios de solución, unas necesidades espirituales totalmente dispares [...] no se pretenda ver en lo anterior ningún pórtico al historismo relativista, pero sí un fuerte reclamo a enfocar la historia históricamente, a recalcar el ser del hombre como ente histórico. El estudio de los filósofos en su biografía profunda, que es la única auténticamente biográfica, es la única forma de entrar a la intelección honda de las filosofías y, tras ellas, a la integración de la filosofía. No que la filosofía se reduzca a su historia, pero sí que la historia de la filosofía sea aporte indispensable para entender lo que ha sido la filosofía y para estructurar una cabal filosofía integradora; en verdad perenne. ${ }^{168}$

En esta misma línea, se encuentra la distinción que hace Ellacuría entre lo que es planteamiento y lo que es solución; entre lo que es visión de realidad y lo que es su objetivación en conceptos:

Siempre he estimado que lo decisivo en el mundo de la cultura es acertar con las preguntas, con el planteamiento hondo de los problemas. Logrado eso, la hondura de las soluciones es mera consecuencia de aquel esfuerzo original y primitivo. La pregunta, en efecto, es la que nos instala en una u otra profundidad, la que abre un ventanal a unos horizontes estrechos e indefinidamente extendidos. ${ }^{169}$

La distinción se hace para resaltar que, tras las apariencias balbucientes de los presocráticos, se dan en ellos logros importantes. Uno de ellos es, justamente, que sitúan el preguntar en un nivel nuevo, desde el que se van a descubrir perspectivas desconocidas de la realidad. Si bien sus respuestas y soluciones son pobres por falta de técnicas y recursos, no se puede decir lo mismo de su planteamiento de los problemas. Algo similar se puede decir de su visión de la realidad, a diferencia de lo que es la objetivación de esa realidad en conceptos: 
Las ideas, desde luego, tienen un haz abstracto, cuya validez como significado es independiente de toda subjetividad; pero, por el otro haz, son indudablemente una cuestión humana, resultado de un habérselas el hombre con las cosas, de un efectivo trato con ellas. Para captar aquella vertiente abstracta viene bien enfrascarse en esta otra concreta de la que fueron histórico resultado; sin embargo, no se agota ahí la eficacia, ya que además de lo que se dice puede importar lo que se pretendió decir, en cuanto tal pretensión descubre una visión primigenia a la que los conceptos que la pretenden explicar no acaban de amoldarse por su tosquedad primitiva. ${ }^{170}$

El concepto presupone una cierta visión intelectual previa, sin la cual no pasaría de ser una forma vacía de contenido. Por otro lado, se puede tener una visión o intelección espléndida de realidad y no lograr, sin embargo, una conceptuación que esté a la altura de aquella visión. Para Ellacuría este es un fenómeno que ocurre en todos los niveles de la vida personal y de la vida cultural, pero que aparece con peculiaridad en la filosofía. El secreto del exegeta estará en descifrar tras las objetivaciones conceptuales las visiones de realidad que en ellas se esconden. Redescubrir la plenitud de la visión intelectual encubierta o recortada por ciertas objetivaciones debidas al carácter histórico del pensamiento es, para Ellacuría, la tarea del historiador de la filosofía y de todo filósofo que reconozca el carácter histórico de su ciencia.

Son estos elementos de la filosofía zubiriana los que hacen que Ellacuría perciba en Zubiri a un filósofo que le puede dar un avance y profundización en el terreno de los existencialismos e historicismos como base para hacer realmente una síntesis -y no un mero conglomerado- entre la filosofía clásica y la filosofía moderna, percepción motivada por la lectura de Naturaleza, Historia, Dios, obra en la que, según Ellacuría, Zubiri se muestra en posesión de ambas filosofías y en la que se apunta la posibilidad de esa síntesis, "por su capacidad crítica, de profundización, de equilibrio y unificación"171. Y es con esta motivación con la que se decide hacer la tesis doctoral sobre su pensamiento. Pero, como el mismo Ellacuría le confiesa a Zubiri, su asombro fue mayor, después de la lectura de Sobre la esencia ${ }^{172}$, pues encontró más de lo que esperaba:

170 Ibídem, p.74-75.

171 Carta de I. Ellacuría a X. Zubiri, 23 de febrero de 1963. Archivo Ignacio Ellacuría, UCA, San Salvador.

172 X. Zubiri, Sobre la esencia, Madrid, 1962. 
Lo que me pasó fue que el libro fue un deslumbramiento en un terreno en el que me parecía que ni ya cabía en él deslumbramiento 0 , al menos, no respecto a una persona familiarizada con lo que los clásicos habían escrito [...]. El asombro ha sido, entonces, que Vd. ha dado todo esto de una forma superior, como quien da una solución no al problema mal propuesto, sino a un problema que primero había que replantear [...]. Desde luego no se dirá que su filosofía, ni aun siquiera su filosofar, sea aristotélico o escolástico [...]. La prueba mejor está en los resultados: allí donde la escolástica se ha detenido en sus soluciones sea porque no ha visto más realidad discutible, sea porque se ha contentado con explicar la realidad entrevista de un modo negativo, Vd. va adelante en presentar más realidad -no sólo realidades- y en presentarla en su ser positivo [...]. Así como el escolasticismo está tantas veces trascendido, así lo está también la filosofía que hoy corre más como moneda corriente [...]. Lo que en este aspecto asombra es su radical modernidad y su radical despreocupación por parecer moderno, su radical independencia de lo que pudiera llamarse moda filosófica. Su libro está escrito sin concesiones, sólo atento a una consideración independiente de la realidad, tal como la realidad se presenta a un hombre que, además de su extraordinario talento filosófico, está equipado para hacer una filosofía -y no cualquier parcial discusión filosófica- desde hoy en la línea de siempre. Sobre el ordinario pensar moderno yo caracterizaría al suyo con la palabra totalidad: totalidad para abarcar todo lo que el tema encierra en sí frente al permanente inacabamiento e inconclusión de muchos libros filosóficos de hoy, y totalidad para radicar las apariencias y los análisis fenomenológicos en la estructura misma de la realidad. 173

De hecho, Sobre la esencia representa una de las obras más importantes del pensamiento de Zubiri y en la época de los años sesenta y setenta fue considerada como la obra definitiva del filósofo vasco, cosa que actualmente, después de la publicación de la trilogía zubiriana de la inteligencia, a principios de los años de los ochenta ${ }^{174}$, ya no se puede considerar sin más. En el pensamiento filosófico de Zubiri se pueden reconocer tres etapas fundamentales: una 
primera etapa fenomenológica u "objetivista" (1921-1931) en la que recibe la influencia sucesiva de E.Husserl, J.Ortega y Gasset y Martin Heidegger, autores que le abren un horizonte de un pensamiento decisivamente crítico de la modernidad. ${ }^{175}$ Una segunda etapa “ontológica” (1932-1944), en la cual la influencia de Heidegger se hace más patente, aunque ya Zubiri comienza a tomar distancia de la "comprensión” heideggeriana y orienta su pensamiento hacia la búsqueda de una lógica de la realidad y no del ser. Zubiri ya está instalado en la "aprehensión de realidad", que lo sitúa más allá de la "conciencia fenomenológica" husserliana, la "vida" orteguiana y la "comprensión del ser" heideggeriana. Aquí se ubican los artículos recogidos en Naturaleza, Historia, Dios (1944). En la tercera y última etapa (1945-1983), propiamente zubiriana, se da una clara superación de las posturas mantenidas en las etapas previas: "en ella se consuman las dos grandes metamorfosis ya preludiada en la etapa anterior: una primera es la metamorfosis epistemológica, el abandono de la idea de conciencia por la de intelección sentiente, y otra la metafísica, el paso definitivo desde el ser a la realidad". ${ }^{176}$

Sobre la esencia pertenece a esta etapa y en ella Zubiri desarrolla una filosofía de la realidad distanciado tanto de la filosofía moderna de la subjetividad como de la tradición escolástica, pero también del idealismo fenomenológico de Husserl y de la filosofía de Heidegger: "En el fondo, toda la filosofía de Heidegger es un comentario a esta idea de que el hombre es el comprensor del ser. No es de extrañar. Heidegger ha partido de la Fenomenología, y pese a las hondas, radicales, transformaciones, que en ella introduce, sin embargo, permanece en el ámbito fenomenológico. Para la Fenomenología, lo primario y fundante es siempre y sólo la conciencia, como ente en el cual y sólo en el cual se dan las cosas en lo que ellas verdaderamente son. Heidegger supera la idea de conciencia mediante la idea de comprensión, y supera la idea del darse de las cosas mediante la idea del phainestai, de aparecer en el sentido de mostrarse. Este mostrarse es mostrarse como siendo. Ser es entonces la posibilidad de que las cosas se muestren y de que el hombre las comprenda. Con lo cual, lo radical en el hombre se torna en comprensión del ser. Ahora bien, esto es insostenible, primero, porque la función primaria del hombre no es comprender el ser, sino enfrentarse sentientemente con la realidad de las cosas, y segundo, porque el ser carece de toda sustantividad; el ser sólo es respectivamente; y esta respectividad no es la respectividad al hombre, sino a la realidad de todo. Por tanto, es la realidad y sólo la realidad lo que tiene sustantividad". 177

175 Cfr. D. Gracia, Voluntad de verdad. Para leer a Zubiri, Editorial Labor, Barcelona, pp. 33-74. 176 Cfr. ibídem, p. 100.

177 X. Zubiri, Sobre la esencia, op.cit., pp. 456-457. 
Así Ellacuría encuentra en esta obra de Zubiri un nuevo horizonte filosófico y una nueva filosofía, que efectivamente supera las anteriores, "no sólo en su modo sino también en su contenido", lo cual permite "edificar sobre ella un cuerpo entero de filosofía" a partir de un apoderamiento efectivo y radical de la realidad ${ }^{178}$. En primer lugar, Ellacuría ve en el nuevo concepto de la esencia y de la realidad que propone Zubiri, una base para hacer una consideración existencial e histórica del hombre, una dimensión ignorada por la escolástica. En segundo lugar, frente al existencialismo y el vitalismo, que entienden la vida humana como puro suceso, Ellacuría resalta la radicalidad del planteamiento zubiriano al presentar la vida humana como radicada en una realidad o esencia cuyo rasgo esencial, no es primariamente su ser histórico o sucesivo, sino su carácter de autoposesión. ${ }^{179}$

Pero el hallazgo radical de Zubiri en Sobre la esencia, reside, a juicio de Ellacuría, en la idea de realidad entendida como esencia y desde la esencia, en el caso de la realidad humana, haber encontrado el modo de radical, respetándolas en su respectivo carácter, lo que hay de naturaleza y lo que hay de historia en la realidad que es una. A juicio de Ellacuría, no se trata de una conciliación ni menos de una mera yuxtaposición, sino de una profundización que lleva a Zubiri a transformar la idea misma de esencia para que en forma coherente y unitariamente pueda ser en su caso naturaleza e historia:

[...] su nueva concepción de la esencia y de la realidad da una magnifica e inmediata base para una nueva consideración existencial del hombre, cosa que no ocurre con la escolástica. Y esto porque ha radicalizado de tal modo la cuestión que presenta el fondo de una esencia capaz de abarcar tanto las esencias naturales como las esencias históricas, consecuentemente al hombre como naturaleza e historia. Por eso se puede decir con verdad que su pensamiento es transescolástico y trans-filosofía actual. $Y$ en este sentido me pone de bruces en el tema central

178 Carta de I. Ellacuría a X. Zubiri, 23 de febrero de 1963, op.cit.

179 Cfr. Entrevista con X. Zubiri, Madrid, 18 de octubre 1963, Archivo Ignacio Ellacuría, San Salvador. En esta entrevista, Ellacuría define el tema de su tesis en la dirección de la novedad radical que percibe en el planteamiento zubiriano: "El tema que le propuse como tesis era el de la principialidad de la esencia frente a la presunta principialidad de la existencia, lo cual me permitiría familiarizarme con algún existencialista serio, y frente a la principialidad del ser lo cual me obligaría a meterme con el tomismo alemán hoy (...) le propuse entonces el plan de mi tesis: 1) Sustancia y sustantividad: la filosofía de Zubiri frente al aristotelismo y la metafísica clásica; Ser y realidad: su filosofía frente al neotomismo alemán; 3) Existencia y esencia: su filosofía frente al existencialismo, para concluir con lo que es el tema de la tesis: Principialidad de la esencia; exposición del problema mediante el pensamiento de Zubiri". 
que me interesaba tratar en Zubiri: la superación de dos filosofías que como resultados son inconciliables. ${ }^{180}$

Y en otro texto, afirma:

Porque Zubiri no ha considerado al hombre tan sólo como un trozo de la naturaleza que puede ser captado adecuadamente por lo que se ha dado en llamar ciencias naturales. Es también historia. Y Zubiri ha hecho justicia a este aspecto esencial del hombre. No era poco atender equilibradamente a estos dos aspectos del hombre, y Zubiri lo realizó ya desde los tiempos de Naturaleza, Historia, Dios. Ahora ha hecho más. Mostrar cómo no se trata de dos aspectos meramente yuxtapuestos y señalar cómo ambos aspectos se radican en una unidad esencial. La verdadera dificultad era, por de pronto, presentar al hombre que es naturaleza e historia no quedándose en la parcialidad de ninguno de los dos extremos; y, después, intentar mostrar la unidad de esos dos momentos, trascendiéndolos, en la estructura esencial de la que nacen. Por ser el hombre última y unitariamente lo que es, es, a la vez, naturaleza e historia, hecho y suceso. ${ }^{181}$

Este es el punto que marca el momento en que Ellacuría abandona su proyecto de conciliación y el de su ruptura con proyectos similares como el del neotomismo alemán ${ }^{182}$. A partir de aquí y hasta su muerte, la base de su filosofar será la teoría de la realidad, la teoría de la inteligencia, la antropología y la filosofía de la historia de Zubiri.

La relación de Ellacuría con Zubiri no se reducirá sólo a la profunda influencia que ejerció la filosofía zubiriana en su pensamiento filosófico, sino también se traducirá en una estrecha colaboración intelectual y una íntima amistad que se extenderá por más de veinte años, hasta el deceso de Zubiri en 1983. Desde que hizo su tesis doctoral con él se hicieron amigos y Zubiri decidió que Ellacuría fuera en adelante su estrecho colaborador. A partir de ahí, Zubiri no daba ningún curso ni publicaba nada que no hubiera sido revisado antes por Ellacuría. ${ }^{183}$ “Ellacuría viajaba todos lo años a Madrid, se hospedaba en casa de su hermano

180 Carta de I. Ellacuría a Luis Achaerandio, Bilbao, 22 de marzo de 1963, Archivo Ignacio Ellacuría, San Salvador.

181 “Antropología de Xavier Zubiri”, Revista de Psiquiatría y Psicología Médica de Europa y América Latina (6-7), Año XII, Tomo VI, Barcelona, 1964, pp 5-6.

182 Cfr. "Fundamentación de la metafísica”, Razón y Fe, No. 806, 1965, EF I, pp 589-592.

183 Cfr. R. Cardenal, “Ser jesuita hoy en El Salvador, op.cit., p. 1015. 
pequeño, Juan Antonio, y de su cuñada, Manuela Balenciaga (incluso durante el período en que éstos vivieron en París, Ignacio Ellacuría utilizó su apartamento madrileño), pasaba la jornada entera junto a Zubiri, incluida la cena en casa de éste, seguía sus seminarios, leía los escritos preparados por Carmen Castro, los rehacía, los criticaba junto a Zubiri y los dejaba a punto de su publicación. Así surgieron los numerosos artículos de Zubiri de aquellos años y la importante trilogía: Inteligencia sentiente (1980), Inteligencia y logos (1982), Inteligencia y razón $(1983)$, sin duda su obra magna". ${ }^{184}$

Pedro Laín Entralgo ha descrito elocuentemente esta relación durante los años en que Ellacuría trabajó más de cerca con el filósofo vasco:

¿Qué haces en Madrid? Ante todo, ayudas filial y fraternalmente a Xavier Zubiri. Con tu gran inteligencia, tu ancho saber y tu fino discernimiento, sirves de apoyo intelectual y afectivo a Zubiri, para que éste, en la plenísima y luminosa madurez de sus setenta y ocho años, siga haciendo filosofía [...] Y tú, consciente, como Hegel, como el propio Zubiri, de que sin 'filosofía pura' no es posible la plena dignidad histórica de los pueblos, aunque esa filosofía sea doloridamente crítica, porque al filósofo no le sale de otro modo, tú, con la enorme autoridad personal que te dan esos meses anuales de residencia en El Salvador, donde tan ejemplar y eficazmente sabes poner teoría válida al servicio de una praxis liberadora, con no menos ejemplaridad y eficacia ayudas a que Zubiri haga filosofía pura, la suya. ${ }^{185}$

Una buena parte de sus escritos filosóficos los dedicará Ellacuría a exponer y divulgar el pensamiento de Zubiri, en los que buscará deshacer cualquier interpretación escolástica que se pudiera hacer de su filosofía y mostrar así la novedad filosófica y la crítica radical de Zubiri a la tradición filosófica occidental. Sin embargo, Ellacuría nunca se limitará a ser un mero divulgador del pensamiento zubiriano. Su producción filosófica distará mucho de constituir una simple repetición o una mera exégesis de la filosofía de Zubiri, sino que siempre tratará de ir más allá de ella mediante su prolongación y proyección hacia nuevos campos y nuevas situaciones; en otras palabras, intentará historizarla para sacarle el máximo provecho con miras a la estructuración de una filosofía liberadora y con el fin de resolver los problemas que plantea

184 José Sols Lucia, La teología histórica de Ignacio Ellacuría, op.cit., p.28.

185 P. Laín Entralgo, “Carta a Ignacio Ellacuría”, Revista Estudios Centroamericanos (ECA), No. 346, 1977, p. 610. 
la realidad latinoamericana. En esto fue consecuente con su idea de filosofía como forma de vida: más que un sistema filosófico definitivo, en Zubiri encontró el tipo de filosofía que le suscitó su facultad personal de filosofar.

\section{Conclusión: aspectos principales de la filosofía juvenil de Ignacio Ellacuría} A manera de conclusión, expondremos, a continuación, los rasgos o aspectos principales de la filosofía de Ellacuría que hemos analizado, con el fin de trazar los puentes con su filosofía madura, la cual se empieza a desarrollar después de la realización de su tesis doctoral sobre la filosofía de Zubiri. ${ }^{186}$

- La filosofía como forma de vida. Este es una de las dimensiones más características del pensamiento filosófico de Ellacuría, y es la que ha sido más resaltada por los autores que han estudiado su pensamiento. La filosofía como forma de vida significa adoptar la actitud radical del filosofar mismo y extenderla a la propia vida. La filosofía no es un mero ejercicio intelectual extrínseco a la vida del filósofo y a los problemas que enfrenta vitalmente en su situación. Esto lleva a que el filósofo se involucre vital y existencialmente con la desvelación y revelación de la realidad que se le hace presente como problema en su propia experiencia vital e histórica.

- El punto de partida: el problema existencial del hombre contemporáneo dentro de la civilización occidental. Su insatisfacción con la escolástica y su apertura a las modernas corrientes vitalistas y existencialistas se explica por la orientación humanista que Ellacuría quiere imprimirle a la filosofía, a partir de su visión crítica de la civilización occidental y de los problemas humanos y sociales de las sociedades capitalistas. Estas sociedades someten a los seres humanos a un modo de ser y de vivir que los aliena de su ser verdadero, les cierra su apertura a la trascendencia y les corta la posibilidad misma de lo espiritual. Se trata, por tanto, que la filosofía se oriente a la superación de la alienación humana en esta circunstancia histórica, buscando que el ser humano reconcilie su existencia vital con su esencia verdadera, que es fundamentalmente una esencia religiosa.

- La filosofía como metafísica. Esta tarea humanista y liberadora de la filosofía es posible debido a la naturaleza de su saber y a su enorme potencialidad para encontrar la verdad y el ser de las cosas, más allá de las apariencias y de lo superficial. Por ello es necesario que la filosofía se constituya como un saber radical, total y último si es que pretende iluminar y orientar la

186 Principialidad de la esencia en Xavier Zubiri, tesis doctoral en la Universidad Complutense, Madrid, 3 tomos, 1965, $1094 \mathrm{pp}$. 
vida humana. Se trata de hacer filosofía hoy en la línea de siempre; es decir una filosofía que afronte los temas capitales que afectan al ser humano en nuestro tiempo, aprovechando los aportes y las técnicas de las filosofías contemporáneas, pero que a su vez se alimente con lo permanente y universal de los filósofos clásicos. Para Ellacuría, la filosofía es un modo excepcional del bios theoretikós, y lo que la distingue de otros saberes es justamente su propósito de ir más allá de la realidad dada por medio de la lucha crítica contra las apariencias y los pensamientos ideologizados que encubren la realidad. Sistematicidad, radicalidad y ultimidad son las características que debe tener una filosofía si es que pretende ser filosofía, $y$, además, ser filosofía con una función vitalizadora y humanizadora.

- Búsqueda de una visión unitaria, dinámica y abierta de la realidad que integre adecuadamente su momento natural y su momento histórico. En el intento de vitalización del tomismo se expresa la insatisfacción de Ellacuría con las soluciones filosóficas que se han dado históricamente al problema de la realidad. Si se ve la realidad como siendo sólo naturaleza, no se explica adecuadamente la especificidad de la realidad humana, su apertura y su intrínseca dimensión histórica, con lo que se recae en un naturalismo; y si sólo se la ve como siendo puro suceso, existencia e historia, se pierde de vista su fundamento real y su radicación en la realidad física, con la consecuente recaída en el idealismo del sujeto. La realidad no es sólo naturaleza (naturalismo, fisicismo, positivismo, materialismo) ni es sólo historia (subjetivismo, historicismo, vitalismo, existencialismo, idealismo). Se trata de encontrar una filosofía que fundamente la totalidad de la realidad como siendo, a la vez, naturaleza e historia, pero determinada en última instancia por su radical apertura, dinamicidad e historicidad. Esto es justo lo que Ellacuría busca y encuentra en la filosofía de Zubiri, y es lo que explica, finalmente, el entusiasmo y la pasión con la que asumió la filosofía zubiriana a lo largo de su trayectoria intelectual.

- Orientación hacia la consideración de la historia como lugar pleno de realidad. No es que se afirme que en esta primera fase de su evolución filosófica, Ellacuría tuviese claro y fundamentado lo que será después una de las tesis centrales de su pensamiento maduro. Lo que se afirma es que en la búsqueda de una visión unitaria y abierta de la realidad, y por influjo principalmente de Ortega y del Zubiri de Naturaleza, Historia, Dios, Ellacuría empieza a tomar conciencia de la importancia metafísica de la historia. La historicidad, como dimensión real de la realidad humana, y la historia, como dimensión de la realidad en la que se produce la imbricación de hombre y mundo, se convierte en la realidad radical y en el lugar por 
antonomasia de revelación de la realidad. Esta es una idea que Ellacuría no ha logrado perfilar totalmente en este momento, pero que, de alguna manera, ya está incoada en su pensamiento y en su búsqueda filosófica. Es una idea que está formulada incipientemente en los análisis que Ellacuría hace de la antropología orteguiana y que, por lo mismo, está formulada con las categorías y conceptos propios de esa antropología, pero yendo más allá de Ortega: la vida humana tomada en su concreción es, a la vez, esencia y existencia, naturaleza e historia; es la unidad dinámica y efectiva de un yo en un mundo y de un mundo en un yo, y sólo desde esta perspectiva total se le puede considerar como la realidad radical.

Estos aspectos encontrarán su desarrollo y transformación en las siguientes etapas de la evolución filosófica de Ellacuría, hasta culminar en su filosofía de la realidad histórica, cuya génesis y constitución, así como sus tesis centrales, serán objeto de otros artículos. El objetivo primario de este estudio ha sido conocer su filosofía temprana con el fin de identificar las raíces de su filosofía madura, así como los temas e intereses filosóficos que le llevaron a asumir la filosofía de Zubiri como base de su reflexión filosófica y de su filosofía más original.

\section{Bibliografía}

Cardenal, R., “Ser jesuita hoy en El Salvador”, Revista Estudios Centroamericanos (ECA), nos. 493-494, 1989.

Ellacuría, I., “Ángel Martínez, poeta esencial”, Revista Cultura, No. 14, 1958. Ellacuría, I., “Antropología de Xavier Zubiri”, Revista de Psiquiatría y Psicología Médica de Europa y América Latina (6-7), Año XII, Tomo VI, Barcelona, 1964.

Ellacuría, I., “El P. Aurelio Espinosa Pólit, S.J.”, ECA, No. 178, 1963.

Ellacuría, I., “El tomismo, ¿es un humanismo?”, ECA, No. 157, 1961.

Ellacuría, I. , “Filosofía en Centroamérica”, Revista de Humanidades, Universidad de El Salvador, Nos. 2-3.

Ellacuría, I., “Utopía y profetismo desde América Latina”, Revista Latinoamericana de teología (17), 1989.

Ellacuría, I., Escritos Filosóficos I, UCA Editores, San Salvador, 1996.

Ellacuría, I., Principialidad de la esencia en Xavier Zubiri, tesis doctoral en la Universidad Complutense, Madrid, 3 tomos, 1965.

González, A., “Aproximación a la obra filosófica de Ignacio Ellacuría”, Revista Estudios Centroamericanos (ECA) Nos.505-506, 1990.

Gracia, D., Voluntad de verdad. Para leer a Zubiri, Editorial Labor, Barcelona, 1986. 
J. Sobrino, R. Alvarado, R., Ignacio Ellacuría. Aquella libertad esclarecida, UCA Editores, San Salvador, 1999.

Laín Entralgo, P., "Carta a Ignacio Ellacuría”, Revista Estudios Centroamericanos (ECA), No. 346, 1977.

Maier, M., "La influencia de Karl Rahner en la teología de Ignacio Ellacuría", Revista Latinoamericana de Teología (39), 1996.

Martin Maier, "La influencia de Karl Rahner en la teología de Ignacio Ellacuría (II)", Revista Latinoamericana de Teología (44), 1998.

Ortega y Gasset, J., La Historia como Sistema, Revista de Occidente, Madrid, 1970, VI.

Ortega y Gasset, J., ¿Qué es filosofía?, Madrid, 1957.

Ortega y Gasset, J., “Creencia y verdad”, en La idea de principio en Leibniz y la evolución de la teoría deductiva, Buenos Aires, 1958.

Ramírez, S., La filosofía de Ortega y Gasset, Barcelona, 1958.

Whitfield, T., Paying the price, Temple University press, Philadelphia, 1995.

Zubiri, X., Inteligencia sentiente, Madrid, 1980.

Zubiri, X., Naturaleza, Historia, Dios, $6^{\text {a }}$ edición, Madrid, Editora Nacional, 1974.

Zubiri, X., Sobre la esencia, Madrid, 1962. 